UNIVERSIDADE DE SÃO PAULO

FACULDADE DE MEDICINA DE RIBEIRÃO PRETO

DEPARTAMENTO DE BIOLOGIA CELULAR E MOLECULAR E BIOAGENTES PATOGÊNICOS

PROGRAMA DE PÓS-GRADUAÇÃO EM BIOLOGIA CELULAR E MOLECULAR

JOHNNY ALEX ROCKENBACH ZENZEN

Miosina-Va auxilia no transporte de Dinamina-2 e Clatrina para as adesões focais e promove sua desmontagem

Ribeirão Preto - SP

2020 


\title{
Miosina-Va auxilia no transporte de Dinamina-2 e Clatrina para as adesões focais e promove sua desmontagem
}

Tese apresentada ao Programa de Pós-Graduação em Biologia Celular e Molecular do Departamento de Biologia Celular e Molecular e Bioagentes Patogênicos da Faculdade de Medicina de Ribeirão Preto, Universidade de São Paulo para obtenção do título de Doutor em Ciências.

Área de Concentração: Biologia Celular e Molecular

Orientadora: Profa. Dra. Enilza Maria Espreafico

\begin{abstract}
Versão corrigida. A versão original encontra-se disponível tanto na Biblioteca da Unidade que aloja o Programa, quanto na Biblioteca Digital de Teses e Dissertações da USP (BDTD).
\end{abstract}

Ribeirão Preto - SP 
Autorizo a reprodução e divulgação total ou parcial deste trabalho, por qualquer meio convencional ou eletrônico, para fins de estudo e pesquisa, desde que citada a fonte.

Rockenbach, Johnny Alex Zenzen

Miosina-Va auxilia no transporte de Dinamina-2 e Clatrina para as adesões focais e promove sua desmontagem. Ribeirão Preto, 2020.

69f.:il; $30 \mathrm{~cm}$

Tese de doutorado, apresentada à Faculdade de Medicina de Ribeirão Preto, Universidade de São Paulo. Área de concentração: Biologia Celular e Molecular;

Orientadora: Espreafico, Enilza Maria.

1- Miosina Va; 2- Adesão Focal; 3- Dinamina; 4- FAK 


\section{FOLHA DE APROVAÇÃO}

\section{Nome: Rockenbach, Johnny Alex Zenzen}

Título: Miosina-Va auxilia no transporte de Dinamina-2 e Clatrina para as adesões focais e promove sua desmontagem

Tese apresentada à Faculdade de Medicina de Ribeirão Preto da Universidade de São Paulo, para obtenção do título de Doutor em Ciências, área de concentração em Biologia Celular e Molecular.

Aprovada em:

\section{Banca Examinadora}

Prof. Dr(a).

Instituição:

Julgamento:

Assinatura:

Prof. Dr(a).

Instituição:

Julgamento:

Assinatura:

Prof. Dr(a).

Instituição:

Julgamento:

Assinatura:

Prof. Dr(a).

Instituição:

Julgamento:

Assinatura:

Prof. Dr(a).

Instituição:

Julgamento:

Assinatura: 


\section{AGRADECIMENTOS}

- A minha orientadora, Profa. Dra. Enilza M. Espreafico, pela confiança em meu trabalho, paciência, aprendizado e orientação. Pelo entusiasmo com a nossa pesquisa e finalmente por ser uma grande cientista e buscar sempre fazer ciência de qualidade com alto impacto e relevância. É uma honra poder trabalhar ao seu lado, aprendendo cada vez mais.

- Ao Dr. Gregg Gundersen por ter me aceitado em seu laboratório para realização do doutorado sanduíche.

- À Capes, FAPESP, CNPq, Faepa e Faculdade de Medicina de Ribeirão Preto, que forneceram suporte financeiro e estrutura para que este trabalho fosse realizado.

- Ao Laboratório Multiusuário de Microscopia Multifóton, e à Roberta pela paciência e ajuda no multifóton e nas dúvidas sobre imagens e microscopia.

- A Professora Dra. Aline Mara dos Santos e ao Centro Nacional de Bioimagem (CENABIO) pela geração das imagens de microscopia SIM.

- À Silmara, pela dedicação ao nosso laboratório e pela paciência, e por sempre me ajudar com dúvidas nos protocolos e nos cálculos de concentração.

- À Joana, por zelar pela limpeza do laboratório e cuidado com nossos materiais, permitindo a realização deste trabalho e dos demais no laboratório.

- Aos funcionários do Departamento de Biologia Celular e Molecular e Bioagentes Patogênicos, em especial à Vani por sempre fazer o café que nos mantem focados durante o dia, também à Carol, Roseli, Mara, Elizabete, Viviane, Tania, Izilda, Sílvia e o Anderson.

- Às Profa. Dra. Munira M.A. Baqui, Constance Oliver, Roy E. Larson, Ricardo G.P Ramos, Maria Célia Jamur, Maria Luisa Paçó-Larson, Ângela Cruz e Maria Cristina Roque-Barreira, pelos anticorpos, reagentes e equipamentos emprestados, que permitiram o desenvolvimento deste trabalho.

- A todos os docentes do Programa de Biologia Celular e Molecular, que de uma forma ou de outra contribuíram para a minha formação acadêmica e crescimento profissional.

- À Anelisa por me ajudar a dar os primeiros passos dentro do laboratório.

- Às secretárias Lúcia, Camila e Gabriela pela ajuda e paciência. 
- A minha mãe, que mesmo distante apoia cada decisão e me dá suporte e força para continuar. Tudo que conquistei até hoje, é em resultado dos seus conselhos, amor, compreensão, carinho e paciência. E a minha irmã, que é a melhor irmã do mundo, e me dá muito orgulho. Amo vocês. - À minha família, que sempre me incentivou e acreditou em mim e nos meus objetivos.

- À minha noiva Roberta, pelo amor, carinho, paciência, e por estar ao meu lado mesmo nos momentos difíceis.

- Aos amigos da pós-graduação, Mario, Felipe, Denyse, Camlia, Henrique, Luís, Rodolfo, Gustavo, Juliana, Douglas, Giovana, Lucas por tornarem os dias de trabalho mais agradáveis e compartilharem da mesma angústia e alegrias da vida pesquisador.

- Aos amigos do laboratório, os antigos e os recentes pela companhia, amizade, paciência e incentivo. Carmen, Anelisa, Carlos, Cibele, Denise, Mariani, Roberto, Rodrigo, Rui, Cristiano, Lucas, Jackeline, Yasmin, Airton e Santiago.

- O presente trabalho foi realizado com apoio da Coordenação de Aperfeiçoamento de Pessoal de Nível Superior -Brasil(CAPES) - Código de Financiamento 001. 


\section{RESUMO}

\section{ROCKENBACH, J. A. Z. Miosina-Va auxilia no transporte de Dinamina-2 e Clatrina para}

as adesões focais e promove sua desmontagem. 2020. Tese (Doutorado em ciências) Faculdade de Medicina de Ribeirão Preto, Universidade de São Paulo, Ribeirão Preto, 2019.

A montagem e desmontagem das adesões focais (AFs) desempenham um papel fundamental em vários processos celulares, incluindo migração celular, proliferação e sobrevivência. As adesões focais são desmontadas na parte traseira e montadas na parte dianteira, durante a migração celular. Resultados anteriores do nosso laboratório mostram que a perda ou redução da expressão de miosina-Va (MVa) fibroblastos e células de melanoma causam uma redução significativa nas taxas de migração e invasão. Aqui demonstramos que os fibroblastos silenciados para MVa sofrem um atraso dramático na desmontagem das AFs, o que implica que a atividade motora da MVa é essencial para promover a desmontagem. A desmontagem é necessária para que ocorra a reciclagem de componentes das AFs, permitindo que a célula remonte novas AFs na frente migratória e migre corretamente. Os microtúbulos apresentam um papel fundamental na desmontagem das AFs e são necessários para levar proteínas para as AFs, como a dinamina-2, uma GTPase necessária para a endocitose da integrina mediada por clatrina. Os resultados prévios do meu mestrado mostraram que a miosina-V fosforilada se localiza nas $\mathrm{AFs}$, durante a rápida formação dessas estruturas induzidas por estímulo com soro fetal bovino. Uma vez que ocorre a formação das AFs em fibroblastos deficientes para MVa, formulamos a hipótese de que a localização de miosina-Va nas AFs é necessária para fornecer fatores de desmontagem e / ou sinalização, resultando na formação de estruturas mais dinâmicas do que as formadas na ausência de MVa. O presente projeto propôs monitorar a dinâmica molecular das AFs: montagem, desmontagem e reciclagem, em células controle e deficientes em MVa. Mostramos aqui que componentes do soro fetal bovino, como EGF e LPA induzem a fosforilação da MVa em células quiescentes e que a MVa auxilia no transporte de Dinamina-2 e Clatrina para as adesões focais e promove sua desmontagem.

Palavras-chave: Miosina-Va, Adesão Focal, Dinamina, FAK. 


\begin{abstract}
ROCKENBACH, J. A. Z. Myosin-Va assists in the transport of Dynamin-2 and Clathrin to focal adhesions and promotes their disassembly. 2020. Tese (Doutorado em ciências) -
\end{abstract} Faculdade de Medicina de Ribeirão Preto, Universidade de São Paulo, Ribeirão Preto, 2019.

Assembly and disassembly of focal adhesions (FAs) play a key role in many cellular processes, including cell migration, proliferation and survival. Focal adhesions are disassembled at the rear and mounted at the front during cell migration. Previous results from our laboratory show that the loss or reduction of myosin-Va (MVa) expression in fibroblast and melanoma cells causes a significant reduction in migration and invasion rates. Here we demonstrate that MVa knockdown fibroblasts experience a dramatic delay in disassembly of FAs, implying that the motor activity of MVa is essential to promote FA disassembly. Disassembly is required for FA component recycling to occur, allowing the cell to reassemble new FAs on the migratory front and migrate properly. Microtubules play a key role in disassembling FAs, they are required to deliver proteins into FAs, such as dinamine-2, a GTPase necessary for clathrin-mediated integrin endocytosis. Previous results from my master's degree dissertation showed that phosphorylated myosin- $\mathrm{V}$ is located in FAs during the rapid formation of these structures after fetal bovine serum stimulation. Since FA formation occurs in MVa deficient fibroblasts, we hypothesize that localization of MVa in FAs is necessary to provide disassembly and / or signaling factors, resulting in the formation of more dynamic structures than those formed in the absence of myosin-Va. This project proposed to monitor the molecular dynamics of FAs: assembly, disassembly and recycling, in control and in myosin-Va deficient cells. We show here that components of fetal bovine serum, such as EGF and LPA, induced the phosphorylation of MVa in quiescent cells and that MVa assists in the transport of Dynamin-2 and Clathrin to focal adhesions and promotes their disassembly.

Keywords: Myosin Va, Focal Adhesions, Dynamin, FAK. 


\section{SUMÁRIO}

1. Introdução.......................................................... 11

1.1 Migração Celular........................................................11

1.2 Adesões Focais......................................................... 13

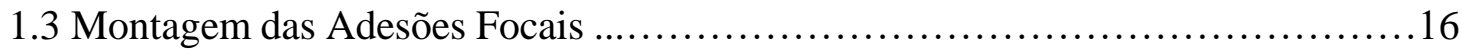

1.4 Desmontagem das Adesões Focais ...................................... 17

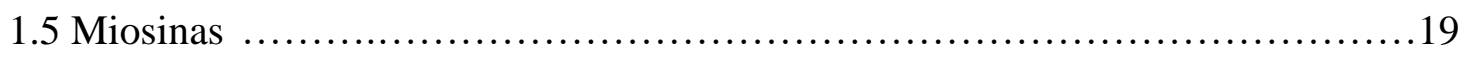

1.6 Miosina-Va ......................................................... 19

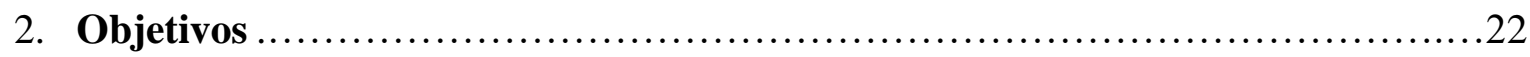

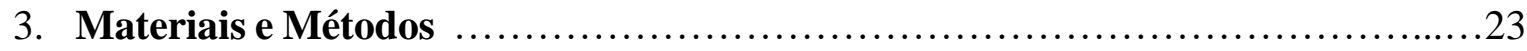

3.1 Cultivo Celular ..........................................................23

3.2 Ensaio de Privação de Soro e estímulo por EGF, Insulina e LPA ...................23

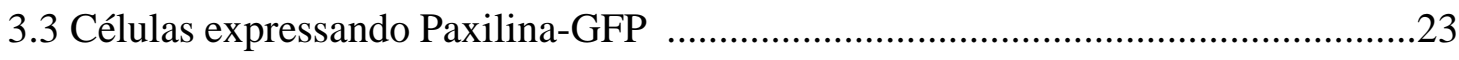

3.4 Nocodazole Washtout - Tratamento com Nocodazol ............................................24

3.5 Eletroforese em gel de poliacrilamida na presença de SDS (SDS-PAGE) .............24

3.6 Imunodetecção de Proteínas (Western Blot) ..........................................................24

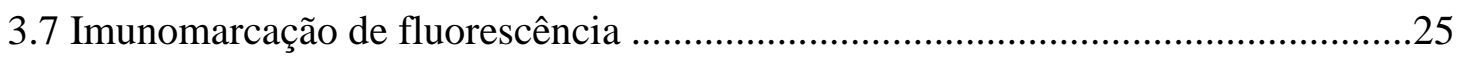

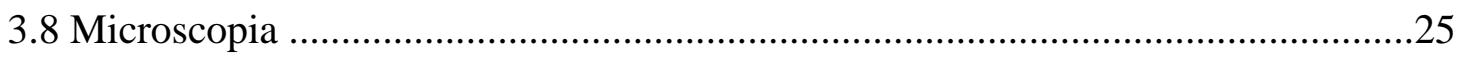

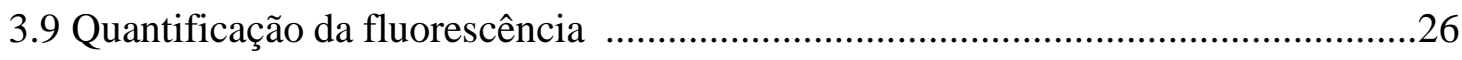

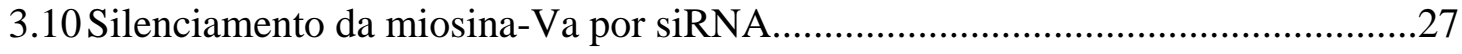

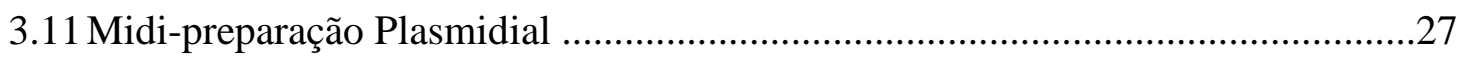

3.11 Trasnfecção de Plasmídeos ..............................................................................29

3.12 Anticorpos primários e secundários utilizados neste trabalho ............................29 
4.1 EGF, Insulina e LPA induzem a fosforilação da miosina-V

4.2 A miosina-V se localiza nas adesões focais após tratamento por nocodazol .39

4.3 A miosina-Va participa da desmontagem das adesões focais .44

4.4 A FAK não afeta o recrutamento da miosina-Va para as adesões focais .49

4.5 A miosina-Va é importante para o recrutamento de Clatrina e Dinamina-2 para as adesões focais

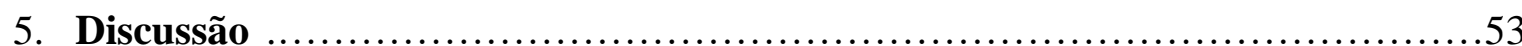

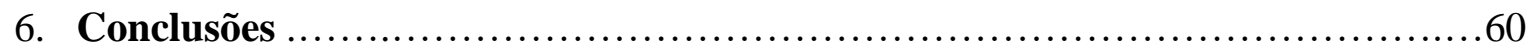

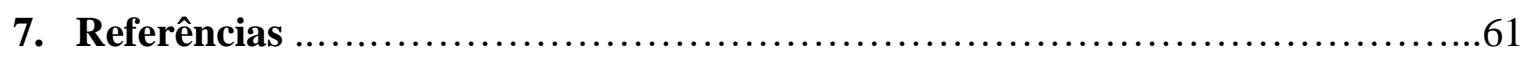




\section{Introdução}

\subsection{Migração Celular}

A migração celular é um mecanismo fundamental que está envolvido em processos como a morfogênese e embriogênese, processos patológicos como doenças vasculares, osteoporoses, retardo mental e câncer (RIDLEY et al., 2003). Assim, a compreensão dos mecanismos fundamentais subjacentes à migração celular trará abordagens terapêuticas mais eficazes para tratar estes e outros processos patológicos. A migração celular requer uma complexa coordenação da transdução de sinais intracelulares e extracelulares, da dinâmica e reorganização dos citoesqueletos de actina e tubulina e das adesões focais (AFs). As AFs conectam o citoesqueleto de actina a matriz extracelular (ME), e além de aderirem a célula também são estruturas mecanosensoras as quais internalizam sinais da ME (DE PASCALIS; ETIENNE-MANNEVILLE, 2017).

A migração é um processo cíclico e envolve a repetição de quatro passos: (1) protrusão da frente migratória, (2) adesão, (3) contração do corpo celular e (4) retração da parte traseira da célula, os quais, são coordenados pela célula e ocorrem de forma sequencial (VICENTEMANZANARES; CHOI; HORWITZ, 2009). A migração celular já foi e continua sendo extensivamente estudada e vários de seus componentes já foram identificados. Para migrar a célula necessita gerar forças que movimentam a membrana plasmática para frente, para isso a célula utiliza quatro tipos de protrusões da membrana plasmática na frente migratória (leading edge): os invadopódios, os blebs, os filopódios e o lamelipódio (RIDLEY, 2011).

Os filopódios são extensões citoplasmáticas da célula e contêm feixes paralelos de actina, os quais induzem sua extensão através da polimerização da actina por WASP e Arp2/3 ou pela formina mDia (RIDLEY, 2011). Sua principal função é exploratória, provendo informações para a célula sobre o meio extracelular, como a presença de células vizinhas e a rigidez da matriz extracelular (JACQUEMET; HAMIDI; IVASKA, 2015).

Os invadopódios são protusões ricas em filamentos de actina associados a degradação da ME durante a invasão celular, essas estruturas são formadas pela polimerização dos filamentos de actina (RIDLEY, 2011), onde há a exocitose de metaloproteases responsáveis pela degradação da ME (POINCLOUX et al., 2009).

Os blebs, estruturas parecidas com balões, não possuem filamentos de actina e são formados em locais em que a membrana plasmática se desprende do córtex de actina levando a 
um influxo de citoplasma na região (CHARRAS; PALUCH, 2008). Essas estruturas podem ocorrer em vários tipos celulares, como células embrionárias e de câncer, mas normalmente são mais observadas em células sobre matriz extracelular flexível (BOVELLAN et al., 2010). Os blebs podem em alguns casos serem a principal força migratória, podem alternar com o lamelipódio ou até aparecer ao mesmo tempo que lamelipódios e filopódios durante a migração (RIDLEY, 2011).

O lamelipódio é uma estrutura fina e extensa que demarca a frente migratória de células mesenquimais (fibroblast-like), onde a arborização da actina por WAVE e Arp2/3 leva a protrusão da membrana plasmática na frente migratória (INNOCENTI, 2018). Arp2/3 está distribuído pelo lamelipódio e está incorporado à actina principalmente na parte frontal do lamelipódio, interagindo com as pontas farpadas de actina e permitindo sua polimerização (LAI et al., 2009). Além de Arp2/3, outros nucleadores como os da família das forminas e de Spire também contribuem para a manutenção do lamelipódio (RIDLEY, 2011). No lamelipódio são observadas AF nascentes as quais possuem uma conexão mais fraca com o citoesqueleto de actina, um fluxo retrogrado mais rápido (movimento retrogrado dos filamentos de actina devido a força aplicada pela miosina II). A região logo após o lamelipódio é chamada de lamela, onde são encontradas adesões maduras, as quais são maiores e contém uma maior concentração de proteínas, tendo assim uma conexão mais forte com o citoesqueleto de actina, um fluxo retrogrado mais lento devido a essa conexão mais robusta com o citoesqueleto. Essa maturação progressiva das AFs somado a força aplicada pela miosina II sobre os filamentos de actina geram a força necessária para impulsionar a célula para frente (SUN; GUO; FÄSSLER, 2016).

No contexto de migração celular mesenquimal essas 4 estruturas são essenciais, nelas há uma forte e determinante participação do citoesqueleto de actina, o qual além de dar sustentação e induzir a protrusão da membrana plasmática, também está envolvido no deslocamento do núcleo (GUNDERSEN; WORMAN, 2013) e na organização espacial da célula em uma frente migratória (YAMASHIRO; WATANABE, 2014). A polarização também é crucial para a migração, a célula possui mecanismos que impedem as protrusões da membrana de ocorrem na periferia da célula, e inibem que as contrações do citoesqueleto aconteçam de forma aleatória, prevenindo atrasos e dificuldades na migração celular. Para isto, ocorre uma organização polarizada na célula, de tal forma que o tráfego de vesículas é direcionado para a frente migratória, há também uma organização dos microtúbulos, onde centro de regulação dos microtúbulos e o golgi se localizam entre o núcleo e a frente migratória (ETIENNEMANNEVILLE, 2013). 


\subsection{Adesões focais}

As adesões focais são estruturas supramoleculares compostas por agrupamentos de integrinas, proteínas transmembrana que funcionam como receptores para componentes da matriz extracelular. As integrinas conectam a célula à matriz extracelular (ME), e nas AFs as integrinas estão associadas a proteínas estruturais, como talina, vinculina, paxilina e alfaactinina que se conectam às fibras de estresse do citoesqueleto de actina, bem como moléculas de sinalização, como FAK (Focal Adhesion Kinase), e Src (CASWELL; VADREVU; NORMAN, 2009). Dessa forma, as AFs desempenham um duplo papel, gerar tensão e transmitir sinais regulatórios para o interior da célula. As AFs podem ser vistas como embreagens moleculares (molecular clutch), as quais se aderem a ME e utilizam a força gerada pela actomiosina para impulsionar a célula para frente durante a migração (SUN; GUO; FÄSSLER, 2016). Entretanto, as integrinas não possuem sítio de ligação com a actina, essa ponte entre integrinas e actina é realizada pela talina, a qual se liga a porção intracelular das integrinas e a actina (KLAPHOLZ; BROWN, 2017).

As AFs transmitem informações de sinalização mecânica e molecular para o citoesqueleto de actina, regulando assim a adesão celular, a migração e a sobrevivência. Para que a migração celular ocorra, as AFs precisam ser desmontadas na parte traseira e remontadas na frente migratória da célula. Os mecanismos de desmontagem das AFs incluem a desmontagem mediada por calpaína e a desmontagem mediada por endocitose. A desmontagem mediada por endocitose pode ser dependente de clatrina ou mediada por caveolina (CASWELL; VADREVU; NORMAN, 2009).

Podemos classificar as adesões em adesões nascentes, adesões fibrilares e adesões focais, dependendo de sua morfologia, composição, localização subcelular e de suas propriedades mecânicas (Figura 1) (SUN; GUO; FÄSSLER, 2016). As adesões nascentes são pequenas adesões na frente do lamelipódio, as quais tem uma "vida" curta e as pequenas GTPases Rac e Cdc42 tem um papel fundamental em sua formação (GUO et al., 2006). A maioria das adesões nascentes é desmontada, mas algumas maturam em AFs na região da lamela. Essa maturação é induzida pela quinase efetora de Rho (ROCK), a qual promove a atividade de miosina II e consiste em um aumento do tamanho da $\mathrm{AF}$, onde integrinas e outras proteínas constituintes das AFs como talina e vinculina são recrutadas e há uma conexão mais robusta entre as adesões e as fibras de actina (STRICKER et al., 2013). Após a região da lamela, ocorre um relaxamento ou até uma perda total da conexão entre adesão focal e actomiosina, e 
as AFs são desmontadas de maneira dependente de clatrina (EZRATTY; PARTRIDGE; GUNDERSEN, 2005), ou são translocadas para uma posição mais central na célula e se tornam adesões fibrilares (Figura 1) (SUN; GUO; FÄSSLER, 2016).

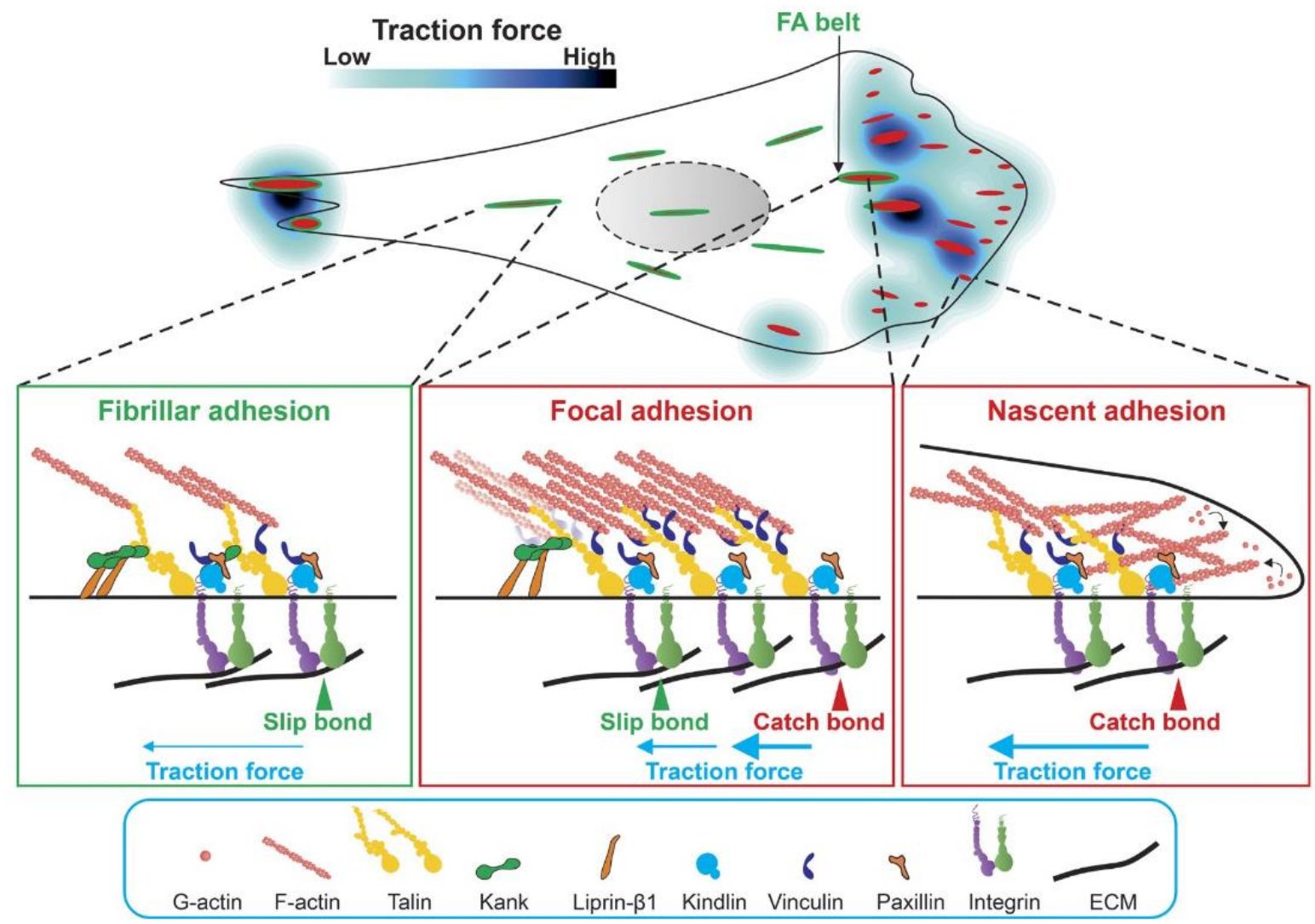

Figura 1: Formação e maturação da adesão célula-matrix durante a migração celular. As adesões nascentes surgem após a ativação das integrinas por kindilina e talina na frente migratória, algumas delas maturam em adesões focais que são mais robustas e onde há uma maior tração para impulsionar a células. As adesões focais são então desmontadas ou translocadas para uma região mais central da célula e perdem ou relaxam a conexão com o citoesqueleto de actina. Retirado de (SUN; GUO; FÄSSLER, 2016).

As AFs são as estruturas que podem ser vistas como os "pés" das células, são estruturas mecanosensoras que conectam o citoesqueleto de actina a ME. Essa conexão adere a célula ao substrato e permite que a célula detecte informações da ME, sinais que ao serem transduzidos pelas AFs induzem uma serie estímulos que direcionam o comportamento da célula (SUN; GUO; FÄSSLER, 2016). AF são clusters de integrinas, glicoproteínas heterodiméricas constituídas por uma subunidade $\alpha$ e uma $\beta$, possuem uma porção extracelular que se liga diretamente a ME, uma porção intermembranal e uma pequena porção citoplasmática 
(KECHAGIA; IVASKA; ROCA-CUSACHS, 2019). Esses heterodímeros são altamente expressos na superfície celular e participam de vários processos biológicos, tais como organização tecidual, crescimento, diferenciação, apoptose e estão envolvidas em processos como inflamação e câncer (ANDERSON; OWENS; NAYLOR, 2014; DESGROSELLIER; CHERESH, 2010; HERTER; ZARBOCK, 2013). Por se ligarem diretamente a ME as integrinas conseguem interpretar a rigidez da ME e transduzir essa informação, gerando adaptações da célula, como: aumentar ou diminuir a força aplicada pelas AF em determinado local, a polaridade da célula, migração, diferenciação e sobrevivência (SUN; GUO; FÄSSLER, 2016). Além disso, as integrinas participam da sinalização celular inside-out e outside-in, onde o primeiro refere-se a sinais produzidos pela própria célula e exocitados, e o segundo por sinas do meio extra celular que são endocitados pela célula, assim transmitindo sinais mecânicos e químicos fundamentais para a sobrevivência e proliferação celular, remodelamento e migração celular (GUO; GIANCOTTI, 2004).

A internalização das integrinas durante a desmontagem das AFs requer a presença de FAK, e ambas podem ser reciclados de volta para a membrana para formar novas adesões focais (EZRATTY; PARTRIDGE; GUNDERSEN, 2005). Muitas evidências sugerem FAK como uma molécula chave nos processos de tumorigênese e progressão tumoral, por promover a sobrevivência, proliferação, migração e invasão das células tumorais. A FAK também regula a migração celular por modular a formação e desacoplamento do citoesqueleto de actina, através de seus efeitos na subfamília de RhoGTPases (ZHAO; GUAN, 2009). A FAK é composta por regiões ricas em prolina e um domínio FAT na região C-terminal, um domínio quinase central e um domínio FERM na região N-terminal que é um importante regulador da atividade de FAK (BAINES; LU; BENNETT, 2014). O domínio FERM pode se ligar à região citoplasmática da integrina- $\beta 1$ (FRAME et al., 2010), constituindo um sítio de sinalização intracelular. Um domínio de ligação, que contém o principal sítio de fosforilação da tirosina, na posição 397, conectando o domínio FERM a parte central da quinase. A fosforilação da tirosina 397 é uma autofosforilação que gera o motivo reconhecido por Src e PI3K (PARSONS, 2003). O domínio FERM da FAK facilita a sinalização das tirosinas quinases receptoras, como o receptor do fator de crescimento epidérmico (EGFR) e o receptor do fator de crescimento derivado das plaquetas (PDGFR) (FRAME et al., 2010). A principal função do domínio FAT é a segmentação de FAK para o complexo de adesão focal, e as mutações neste domínio podem levar à perda desta segmentação devido a uma deficiência na interação com paxilina (PRUTZMAN et al., 2004). 
A nano-estrutura das AFs é extremamente interessante e nos permite vislumbrar como as proteínas estão organizadas. Na parte intracelular há a camada de regulação da actina, onde estão localizadas a actina e proteínas associadas a ela. Em seguida, uma camada de transmissão de força, onde a vinculina e haste da talina estão ligadas a actina transmitindo a força gerada pelo movimento retrogrado da actina sobre as AFs. E por fim uma camada de sinalização das integrinas, onde se encontram as proteínas de sinalização como a paxilina, FAK e as integrinas, além da cabeça $\mathrm{N}$-terminal da talina, a qual se liga diretamente a parte intracelular das integrinas, intermediando assim a conexão entre as integrinas e os filamentos de actina (CASE; WATERMAN, 2015).

\subsection{Montagem das Adesões Focais}

Para que a célula possa migrar as AFs são desmontadas na parte traseira e novas adesões montadas na parte dianteira da célula migratória (ALAHARI; REDDIG; JULIANO, 2002). A endocitose e exocitose da integrina podem ocorrer tanto na parte dianteira quanto traseira da célula, onde a endocitose pode ser através de mecanismos dependentes de clatrina (CASWELL; VADREVU; NORMAN, 2009), ou dependentes de caveolina (SHI; SOTTILE, 2008). No entanto, o mecanismo de internalização das integrinas ocorre dependendo do tipo e contexto celular (ONODERA; NAM; SABE, 2013), onde a endocitose de integrina $\alpha 5 \beta 1$ em fibroblastos é dependente de clatrina e microtúbulos (EZRATTY et al., 2009), e em miofibroblastos ela é dependente de caveolina (SHI; SOTTILE, 2008).

A clusterização de integrinas dá início ao processo de montagem das adesões focais, a interação de kindlina e talina à cauda intracelular da integrina ativa as integrinas, passam de um estado de baixa afinidade para um estado de alta afinidade com componentes da $\mathrm{ME}$ (CALDERWOOD; CAMPBELL; CRITCHLEY, 2013). A vinculina é recruta para as AFs de maneira dependente de tensão via talina, ou independente de tensão via paxilina e a vinculina juntamente com a talina convertem a força gerada pela arborização da actina no lamelipodio em uma força protrusiva para a célula migratória (DE PASCALIS; ETIENNE-MANNEVILLE, 2017). A talina conecta diretamente a integrina aos filamentos de actina e o aumento da tensão sobre o local induz um alongamento da haste da talina, liberando mais sítios de interação com vinculina antes "escondidos" na haste da talina, recrutando mais vinculina para a AF, tornando a AF mais robusta e com uma conexão mais forte com a actomiosina, uma vez que a vinculina se liga à talina e também a actina (HU et al., 2016; KANCHANAWONG et al., 2010) 
A paxilina fosforilada promove o recrutamento da vinculina na forma inativa, a qual é ativada ao interagir com a talina, e vinculina é necessária para manter a talina em uma conformação extendida. Essa conformação extendida da talina expõe mais sítios de ligação com vinculina. A vinculina na forma ativa se liga aos filamentos de actina traduzindo a força gerada pelo movimento retrogrado da actina em uma força protrusiva para a célula (CASE et al., 2015).

\subsection{Desmontagem das Adesões Focais}

Um dos mecanismos utilizados pela célula para a manutenção do bom funcionamento das integrinas é a endocitose. O ambiente ácido dos endossomos primários desligaria a integrina de fragmentos ligados a ela, garantindo assim que os heterodímeros endocitados possam se ligar novamente à matriz quando reciclados à membrana plasmática (CASWELL; NORMAN, 2006). A internalização das integrinas para dissociação dos contatos focais requer a presença de FAK. Ambas podem ser recicladas de volta para a membrana para a formação de novas adesões focais (EZRATTY et al., 2005). Muitos estímulos extracelulares como o fator de crescimento epidermal (EGF) podem induzir a endocitose de integrinas (NING; BURANDA; HUDSON, 2007). Após serem internalizadas para os endossomos primários, as integrinas podem ser direcionadas para a reciclagem ou para a degradação. Essa reciclagem pode ser longa (longloop) via Rab11 a partir do compartimento de reciclagem perinuclear ou curta, diretamente dos endossomos primários para a membrana plasmática (short-loop) via Rab4 (ROBERTS et al., 2001).

Além de estímulos extracelulares, estímulos intracelulares como a força aplicada pelo citoesqueleto de actina sobre as AFs, também podem induzir a sua desmontagem (KUO, 2013). Os microtúbulos desempenham um papel essencial na desmontagem das adesões focais, e são cruciais para a entrega de vesículas e proteínas na frente migratória, mais especificamente levando proteínas que auxiliam na desmontagem até as AFs (NAGANO et al., 2012). Foi demonstrado que a despolimerização dos microtúbulos por nocodazol, seguida pela lavagem do nocodazol (nocodazole washout assay), após a qual os microtúbulos são repolimerizado, induz uma rápida e sincronizada desmontagem das adesões focais, permitindo perceber a importância dos microtúbulos nesse processo (EZRATTY et al., 2009; EZRATTY; PARTRIDGE; GUNDERSEN, 2005). 
Durante a desmontagem das AFs, há uma autofosforilação de FAK no resíduo Y397 (HAMADI et al., 2005), a dinamina-2 é recrutada para as AFs pela FAK e fosforilada pela quinase Src, sendo esse complexo Dinamina-FAK-Src essencial para o turnover das AFs, onde o silenciamento ou mutantes da dinamina-2 são incapazes de realizar a formação desse complexo e apresentam defeito na desmontagem das AFs (EZRATTY et al, 2009; WANG et $a l .$, 2011). Importante ressaltar que recentemente foi demonstrado que a inibição de Src não impede a desmontagem das AFs, mas inibe a remontagem (NADER et al., 2016). A Dinamina é uma GTPase essencial para a fissão da membrana, cuja ação completa a atividade de endocitose mediada por clatrina (FERGUSON; DE CAMILLI, 2012). Existem três parálogos de dinaminas expressas em mamíferos, dinamina-1, dinamina-2 e dinamina-3 (FERGUSON et $a l ., 2009)$, as quais são expressas diferencialmente em diferentes tecidos, sendo a dinamina-2 responsável pela correta endocitose de integrinas $\beta 1$ em células endoteliais (LEE et al., 2014).

A desmontagem das AFs dependente de clatrina se dá por endocitose das integrinas, após o recrutamento de dinamina para as AFs (CHAO; KUNZ, 2009). A via dependente de clatrina ocorre quando a integrina na membrana se liga a Numb, um adaptador de carga específico da endocitose. Numb possui um domínio de ligação à fosfotirosina, o qual se liga diretamente as subunidades $\beta 1$ das integrinas e epsina-15, uma proteína integral de membrana, ubiquitinada, envolvida em criar curvatura da membrana. A clatrina, por sua vez, se liga ao adaptador AP-2, o qual se liga tanto à epsina-15 quanto à clatrina (CASWELL; VADREVU; NORMAN, 2009). Esse complexo juntamente com a dinamina estão envolvidos na endocitose dependente de clatrina.

As AFs também precisam ser desmontadas na parte traseira da célula migratória, embora como mostrado na Figura 1, a tensão nessa região é alta devido a forte adesão da célula a ME nessa região em contraste com a tentativa da célula de se mover para frente, onde por vezes ocorre a quebra da conexão entre citoesqueleto de actina e AF e as integrinas acabam sendo deixadas para trás enquanto a célula continua com a migração (RIDLEY et al., 2003). Através de abordagens proteômicas foi demonstrado que a composição das AFs muda quando a miosina II é inibida. Curiosamente, eles demonstraram que a miosina-Va é um componente de AFs, cuja presença em AFs é dependente da função de miosina II. Portanto, é possível que parte dos componentes envolvidos na desmontagem sejam transportados pela miosina- $\mathrm{V}$ em condições normais, por meio das fibras de estresse, as quais são constituídas por actina e miosina-II, principalmente (KUO et al., 2011). 


\subsection{Miosinas}

O genoma humano codifica 40 genes de miosinas que podem ser divididas em 12 classes (PECKHAM; KNIGHT, 2009), as quais possuem um grande gama de funções celulares como funções citoplasmáticas, funções nucleares no ciclo celular, proliferação e translocação de cromossomos (LANEROLLE; SEREBRYANNYY, 2011). Elas são classificadas em miosinas não convencionais, pois seus dímeros de cadeias pesadas são incapazes de formar filamentos bipolares (HARTMAN; SPUDICH 2012). As miosinas convencionais podem ser subdivididas em miosinas não musculares, que formam filamentos bipolares curtos, ou miosinas musculares que formam filamentos bipolares constituídos por dezenas/centenas de moléculas de miosina, fundamentais para o funcionamento contrátil nos tecidos musculares.

As miosinas-V fazem parte de uma grande família de proteínas motoras baseadas em actina encontradas em todos os organismos eucarióticos. São proteínas compostas duas cabeças motoras, um domínio regulatório ligante de cadeias leves e uma cauda de estrutura, extensão e funções variadas. A cabeça se liga aos filamentos de actina e hidrolisa ATP para gerar energia para caminhar sobre os filamentos de actina. A cauda geralmente medeia as interações com moléculas das 'cargas' que são transportadas pelo motor, ou com outras subunidades de miosina (LARSON, 1996). As miosinas podem participar da citocinese, fagocitose, extensão do cone de crescimento, tráfego de vesículas e organelas (BERG, 2001; MERMALL et al., 1998). Controlam também a organização da actina, morfologia celular e migração (MAKOWASKA et al, 2015). Existem três isoformas de miosina-V codificadas em humanos (Miosina-Va, Miosina-Vb e Miosina-Vc), as quais são diferencialmente expressas em diferentes tipos celulares. A miosina-Vb está envolvida com reciclagem de receptores da membrana plasmática, e mutações nesse gene estão associadas com a doença de inclusão de microvilosidades (KNOWLES et al., 2014). A miosina-Vc está associada ao tráfego de grânulos de secreção, sobretudo em glândulas exócrinas (RODRIGUEZ; CHENEY, 2002). A miosina-Va (MVa) desempenha importantes funções na célula, como reciclagem de receptores de membrana e exocitose (WOOLNER; BEMENT, 2009), transporte de vesículas (LANGFORD, 2002), ancoragem e transporte de proteínas e mRNAs (MCCAFFREY; LINDSAY, 2012).

\subsubsection{Miosina-Va}

A estrutura da MVa, uma miosina não-convencional, é composta por um domínio motor denominado cabeça, o qual contém o sitio de ligação para o ATP e para a F-actina, e se localiza 
na região $\mathrm{N}$-terminal da proteína, seguida por um domínio estrutural chamado de pescoço, que é sua estrutura mais notável ao microscópio eletrônico. Por fim, há uma cauda C-terminal na proteína, a qual se liga às vesículas e componentes transportados pela miosina (Figura 2) (ESPREAFICO et al., 1992; LARSON, 1996). No pescoço se encontra o sítio de ligação à calmodulina (CaM), a qual, juntamente com o cálcio, é necessária para o transporte de vesículas (RECK-PETERSON et al., 2000). Essas miosinas se movem gradativamente ao longo da actina antes de se desligarem, e por possuírem duas cabeças podem dar vários passos sobre os filamentos de actina como uma molécula única (HARTMAN; SPUDICH, 2012; HOWARD, 1997). Esses passos da miosina-V sobre a actina são de $37 \mathrm{~nm}$ cada, e são feitos de "mão em mão", onde cada cabeça ligada a actina se move de uma vez (YILDIZ et al., 2003). O tamanho dos passos da MVa sobre a actina é definido pelo comprimento do pescoço (SAKAMOTO et al., 2005), e dependem da hidrólise do ATP, após a hidrólise a cabeça da miosina V se desprende da actina e dá um passo à frente, se ligando novamente a actina. Então, a cabeça que ficou para trás é fosforilada e o processo se repete (VOLKMANN et al., 2005).

A MVa é um motor molecular baseado em actina e é mais expressa em linhagens celulares de cânceres altamente metastáticos e está envolvida na migração celular de células tumorais (ALVES et al., 2013; LAN et al., 2010). O silenciamento da MVa prejudica o espalhamento das células - propriedade que é dependente das adesões focais; a migração e a invasão celular, bem como o crescimento independente de ancoragem (ALVES et al., 2013). A MVa também pode ter uma interação indireta com microtúbulos atuando no transporte de melanossomos (ESPREAFICO et al., 1992; WU; TSAN; HAMMER, 2005), e servir como um suporte para a quinesina, possibilitando que a quinesina percorra uma distância maior sobre os microtúbulos (ALI et al., 2008).

A rede de conexão entre MVa e a actina representa um modelo conservado, que medeia o transporte de curta distância de organelas (EVANS et al., 2014). Mutações na MVa em humanos levam a defeitos como síndrome de Griscelli (MÉNASCHÉ et al., 2003), uma doença caracterizada por defeitos na pigmentação da pele e dos olhos, e sintomas neurológicos graves (MESCHEDE et al., 2008). Os defeitos na pigmentação são devidos aos problemas com o tráfego de melanossomos, o qual necessita de MVa. Os melanócitos deficientes em miosinaVa apresentam agregação dos melanossomos na região perinuclear (MERCER et al., 1991; NASCIMENTO et al., 1996; WU et al., 1997). A razão para isso, é que os melanossomos, os quais são transportados a longa distância por quinesinas, sobre microtúbulos, falham em ficar ancorados na periferia celular e retornam para a região do centrossomo carregados por dineína 
(WU et al., 1998; WU et al., 2002). Existe também uma associação da MVa ao melanossomo, que envolve a formação de um complexo trimérico entre Rab27a, melanofilina e MVa. A Rab27a se ancora à membrana do melanossomo via lipídeo ligado covalentemente à molécula protéica melanofilina, a qual serve como uma proteína adaptadora (STROM et al., 2002).

A MVa pode estar em uma conformação aberta (ativa) ou fechada (inativa), quando inativa, o domínio da cauda globular da MVa se liga diretamente a região da cabeça, e altos níveis de cálcio ou a interação com o cargo reduzem essa interação, deixando a MVa em sua conformação aberta, liberando a atividade motora (ARMSTRONG et al., 2012; YAO et al., 2015). A fosforilação na Serina-1650 da cauda também é importante para a atividade motora da MVa (KARCHER et al., 2001), e este sítio pode ser fosforilado pela proteína quinase II (CaMKII) (KARCHER et al., 2001), ou por Akt2 (YOSHIZAKI et al., 2007).

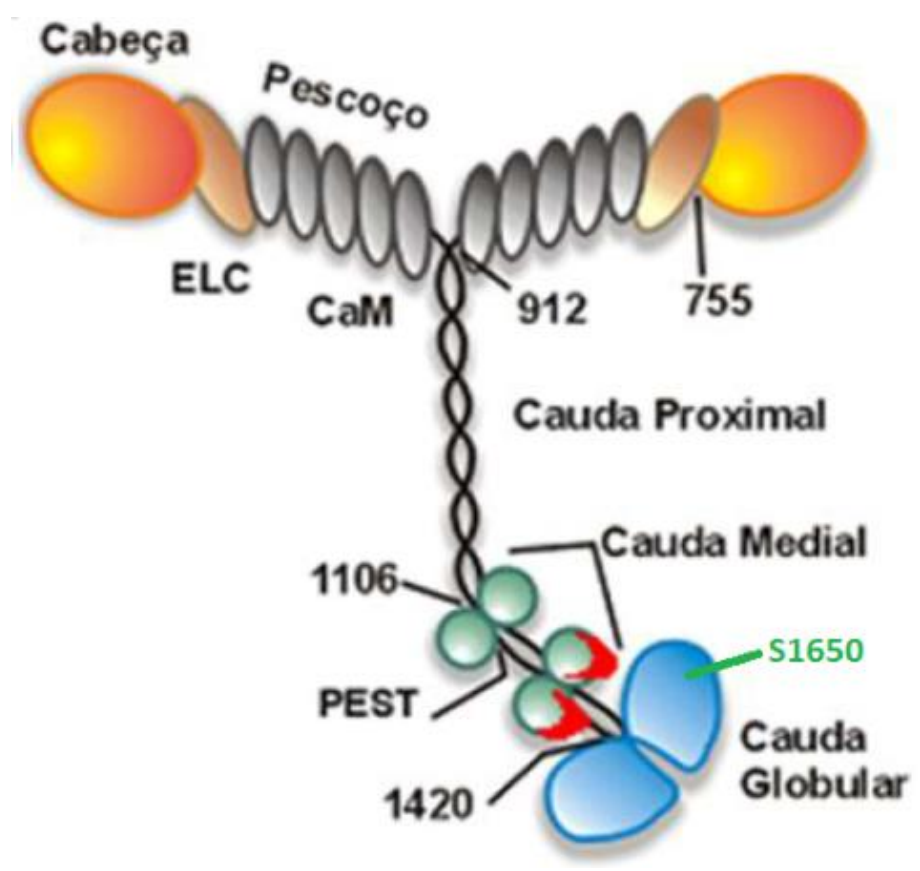

Figura 2: Desenho hipotético esquemático da miosina Va. ELC.: cadeia leve essencial, CaM: calmodulina, PEST: sítio específico de clivagem pela calpaína. Em verde, o sítio reconhecido pelo anticorpo (9E6), produzido e caracterizado em nosso laboratório, referido como miosina- $\mathrm{V}$ fosforilada (pMV) neste trabalho, anticorpo o qual também reconhece miosina- $\mathrm{Vb}$ e miosina-Vc. Os números indicados no esquema correspondem aos aminoácidos onde começam cada domínio. Adaptado de (IZIDORO-TOLEDO; BORGES; ARAÚJO; MAZZI et al., 2013). 


\section{Objetivos}

O objetivo geral do presente estudo foi encontrar as bases moleculares do papel da miosina-Va no processo de migração celular, buscando definir como este motor molecular participa da dinâmica das adesões focais.

1) Determinar se os componentes do soro fetal bovino induzem a fosforilação da miosina-V

2) Analisar a localização subcelular da miosina-Va após estímulo por soro e tratamento com nocodazol.

3) Analisar se a FAK é necessária para o recrutamento da miosina-Va para as adesões focais

4) Investigar se a miosina-Va participa do recrutamento de proteínas essenciais para a desmontagem das adesões focais. 


\section{Metodologia}

\subsection{Cultivo Celular}

Para estudar o papel da miosina-Va em diferentes processos, foram utilizados fibroblastos murinos de origem embrionária - NIH 3 T3 (gentilmente cedidos pelo Dr.Gregg Gundersen (Columbia University - NY), cultivados em Dulbelcco's Modified Eagle's Medium (DMEM) (Life Technologies), pH 6,9 suplementado com 10\% de soro de fetal bovino (SFB) ou Bovine Calf Serum (BCS), sem adição de antibióticos e suplementado com 10mM HEPES $\mathrm{pH}$ 7.4. As linhagens celulares de FAK-/- e DP3 foram cultivadas com Dulbelcco's Modified Eagle's Medium (DMEM) (Life Technologies), pH 6,9 suplementado com 10\% de soro de fetal bovino (SFB), suplementado com 10mM HEPES pH 7.4. Para desprendimento das linhagens celulares foi utilizada solução de Tripsina-EDTA em PBS. Todas as células foram mantidas a $37^{\circ} \mathrm{C}$ em atmosfera úmida contendo $5 \%$ de $\mathrm{CO}_{2}$.

\subsection{Ensaio de Privação de Soro e estímulo por EGF, Insulina e LPA}

Para o ensaio de privação de soro, as células NIH3T3 foram cultivadas em lamínulas até atingirem a confluência de 70-80\% e lavadas com meio DMEM suplementado com 10mM de HEPES pH 7.4 e sem a presença de soro, por 4 vezes antes de serem deixadas em cultura em meio DMEM sem soro por 48 horas. Após $24 \mathrm{~h}$ do plaqueamento as células foram privadas de soro por $48 \mathrm{~h}$. Então, foi dado o estímulo com DMEM suplementado com $10 \mu \mathrm{g} / \mathrm{ml}$ de EGF, 100nm de Insulina ou 100ng/ml de LPA. As células foram fixadas com paraformaldeído 4\% em temperatura ambiente por 10 minutos e preparadas para imunomarcação.

\subsection{Células expressando Paxilina-GFP}

Células NIH 3 T3 foram transduzidas para uma expressão transiente de Paxilina-GFP. Após atingirem uma confluência de $50 \%$ em placas de $100 \mathrm{~mm}$ as células foram infectadas com vírus contendo Paxilina-GFP, após $24 \mathrm{~h}$ da transdução as células foram lavadas, e após $72 \mathrm{~h}$ da transdução as células foram repicadas para impedir que atingissem 100\% de confluência. Após $72 \mathrm{~h}$ as células foram plaqueadas para o experimento em placas de $60 \mathrm{~mm}$ com fundo de vidro, onde após serem privadas de soro por $48 \mathrm{~h}$ foram incubadas com $10 \mathrm{mM}$ de nocodazol por $3 \mathrm{~h}$. Ao final das $3 \mathrm{~h}$ as células foram levadas ao microscópio em câmara a $37^{\circ} \mathrm{C}$ em atmosfera úmida contendo, $5 \%$ de $\mathrm{CO}_{2}$, o nocodazol foi lavado 4x e então foi dado início a obtenção da vídeo microscopia das células vivas. 


\subsection{Nocodazol Washtout - Tratamento com Nocodazol}

As células foram privadas de soro por $48 \mathrm{~h}$ em placas de 24 ou 6 poços, após as $48 \mathrm{~h}$, metade do meio foi removido para adição do nocodazol (concentração final de $10 \mu \mathrm{M}$ por poço), o DMEM com nocodazol foi recolocado nos poços e as células foram incubadas na presença de nocodazol por 3-4h em estufa a $37^{\circ} \mathrm{C}$ e $5 \%$ de $\mathrm{CO} 2$. Após 3-4h de tratamento com nocodazol as células foram lavadas $4 \mathrm{x}$ com meio DMEM sem soro (meio novo e pré-aquecido a $37^{\circ} \mathrm{C}$ ), incubadas a $37^{\circ} \mathrm{C}$ e $5 \%$ de $\mathrm{CO} 2$ para permitir a repolimerização dos microtúbulos. As células foram fixadas com paraformaldeído $4 \%$ em temperatura ambiente por 10 minutos, ou metanol a $-20^{\circ}$ por 5 minutos e preparadas para imunomarcação. As lamínulas foram montadas em fluoromount G para as microscopias confocal e SIM (structured illuminated microscopy), e em PBS 1x para microscopia TIRF.

\subsection{Eletroforese em gel de poliacrilamida na presença de SDS (SDS-PAGE)}

Para verificação das amostras protéicas a eletroforese foi realizada usando o sistema de tampão descontínuo descrito por Laemmli e Favre (1973), em mini-géis (10x9x0,05cm) constituídos de um gel de empilhamento (5\%) e um de separação de $8 \%$ a 12\% de acordo com a massa molecular da proteína em questão. O padrão de peso molecular utilizado foi DualXtra (BioRad).

Todas as amostras, antes de serem aplicadas em SDS-PAGE, foram solubilizadas em tampão de amostra $2 \mathrm{X}$ e fervidas por 5 minutos. Cada amostra foi aplicada nos volumes e 20uL. Para a corrida da eletroforese foi utilizado o tampão de eletrodo (Tris $25 \mathrm{mM}$; glicina $187 \mathrm{mM} \mathrm{e}$ SDS 0,1\%), com amperagem inicial de $15 \mathrm{~mA}$, passando-se para $20 \mathrm{~mA}$ após a entrada das amostras no gel de separação. Em seguida, foram imediatamente submetidos à transferência para membranas de nitrocelulose (BioRad) após o término da corrida.

\subsection{Imunodetecção de Proteínas (Western Blot)}

As proteínas separadas por SDS-PAGE foram eletrotransferidas a $35 \mathrm{~V}$ overnight a $4{ }^{\circ} \mathrm{C}$ para uma membrana de nitrocelulose (BioRad), utilizando-se o tampão de transferência [Trisbase $25 \mathrm{mM}$; glicina $192 \mathrm{mM}$; etanol $18.5 \%$ e SDS 0,1\%]. Após a transferência a membrana foi corada com Ponceau 0,5\% em ácido tricloroacético (TCA) 0,3\% por 10 minutos, sob agitação. A seguir foi lavada com água para remover o excesso de corante e possibilitar a visualização das amostras e eficiência da transferência. 
Antes da imunomarcação, os sítios inespecíficos foram neutralizados com solução de bloqueio (5\% de leite desnatado em pó ou soro albumina bovina em TBS/T [Tris $\mathrm{HCl}$ 50mM pH8,0; $\mathrm{NaCl} 150 \mathrm{mM}$, e Tween-20 0,05\% (V/V)] sob agitação contínua por $1 \mathrm{~h}$ à temperatura ambiente. Após o bloqueio, a membrana foi lavada 3x em TBS/T, sob agitação contínua à temperatura ambiente e incubadas com o anticorpo primário de interesse diluído em TBS/T por 1h sob agitação.

A membrana foi novamente lavada, 4x por 5 minutos em TBS/T, sob agitação contínua à temperatura ambiente para retirar o anticorpo primário não ligado. Foi acrescentado então o anticorpo secundário conjugado com peroxidase, diluído em TBS/T e a membrana, mais uma vez, incubada por $1 \mathrm{~h}$ à temperatura ambiente, sob agitação. Para a retirada do anticorpo secundário não ligado, a membrana foi lavada 4 x por 5 minutos em TBS/T, sob agitação contínua à temperatura ambiente.

A membrana foi banhada com soluções caseiras ECL (Enhanced chemiluminescence), solução I [0,11M Tris/HCL pH 8,5; 2,78mM Luminol (3-aminophthalhydrazide - Sigma); 0,44mM ácido p-cumárico (Sigma); 98,4\% $\left.\mathrm{H}_{2} 0\right]$ e solução II $\left[0,02 \% \mathrm{H}_{2} \mathrm{O}_{2} ; 0,1 \mathrm{M}\right.$ Tris/HCL pH 8,$5 ; 89,9 \% \mathrm{H}_{2} \mathrm{O}$ ] na proporção de de $1: 1$ por 1 minuto. E exposta para captação de imagens utilizando câmera CCD do equipamento ImageQuant LAS 4000 (GE Healthcare). Foram adquiridas imagens a cada 30 segundos e o tempo total de exposição variou de acordo com a amostra em questão.

\subsection{Imunomarcação de fluorescência}

Para este ensaio, as células foram fixadas com paraformaldeído 4\% (Sigma), por 10 minutos a temperatura ambiente. Após a fixação as células foram permeabilizadas com Triton X-100 0,3\% por 10 minutos à temperatura ambiente e então submetidas a três lavagens de 5 minutos em PBS 1X. Os aldeídos livres formados no processo de fixação com paraformaldeído foram bloqueados com Glicina $250 \mathrm{mM}$ em PBS, por 5 minutos. Em seguida, as células foram lavadas 3 vezes de 5 minutos com PBS $1 \mathrm{X}$.

Os sítios inespecíficos foram então bloqueados com BSA 2\% em PBS 1X durante $1 \mathrm{~h}$ à temperatura ambiente. Após a incubação, as células foram incubadas por 1h a temperatura ambiente com o anticorpo primário devidamente diluído em solução de bloqueio e previamente centrifugado a $10.000 x g$ por $1 \mathrm{~h}$ a $4^{\circ} \mathrm{C}$. As lamínulas foram então novamente submetidas a 3 
lavagens de 10 minutos com PBS 1X e incubadas com o anticorpo secundário conjugado com radical fluorescente, diluído em solução de bloqueio.

Terminada a incubação, as células foram lavadas 3 vezes de 10 minutos com PBS 1X. Procedeu-se com a montagem das lamínulas sobre lâminas com a solução de montagem Fluoromount G (Electron Microscopy Sciences) e selagem com esmalte cosmético.

\subsection{Microscopia}

Imagens de microscopia confocal foram obtidas no Laboratório Multiusuário de Microscopia Multifóton, na FMRP-USP, por um AxionObserver (Zeiss, Jena, Germany). Objetiva 63x de imersão a óleo.

As imagens de SIM (structured illuminated microscopy) foram obtidas no Centro Nacional de Bioimagem (CENABIO), USP - Campinas, utilizando o Microscopio de Iluminação Estruturada (SR-SIM). As células coradas por imunofluorescência foram submetidas ao SR-SIM em um microscópio ELYRA S.1 (Carl Zeiss Microimaging), equipado com um laser de 488 nm (100 mW), um laser de 561 nm (100 mW) e uma câmera Andor EMCCD (iXon DU 885). Z-stacks $(0,1 \mathrm{~mm})$ de alta resolução foram coletadas em 5 rotações usando uma objetiva DIC M27ELYRA Alpha Plan-Apocromat 63x/1.46 de imersão a óleo. A aquisição, reconstrução e alinhamento das imagens para microscopia de iluminação estruturada foram realizadas usando o software Zeiss ZEN 2012 SP1 (black edition, versão 8.1.5.484).

As imagens de TIRF (Total Internal Reflection Fluorescence) foram obtidas no laboratório do Dr. Gregg G. Gundersen, Columbia University - NY. As lâminas foram iluminadas com um iluminador TIRF e lasers acoplados a fibra óptica (Ar íon (488 nm) e HeNe (543 nm e $633 \mathrm{~nm})$ ) e cubos de filtro otimizados para fluoresceína / GFP, Cy3 / Alexa Fluor 546, e fluorescência Cy5 (Chroma Technology). Todas as imagens foram capturadas com uma câmera OrcaII ER (Hamamatsu Photonics) usando o software MetaMorph (Molecular Devices). A geração de imagens de células vivas foi realizada em um microscópio invertido (Nikon Eclipse Ti) equipado com um estágio xyz motorizado para gerar imagens de vários campos e um controlador de temperatura $\left(37^{\circ} \mathrm{C}\right)$. Os fibroblastos NIH3T3 que expressam paxilina-GFP de forma estável foram analisados por TIRF ou DIC usando uma objetiva Apocromática 60x. Para microscopia TIRF, as amostras foram iluminadas com um iluminador TIRF e um laser Ar íon (488 nm) acoplado por fibra óptica. Todas as imagens foram capturadas 
com uma câmera (Andor iXon3 888, EMCCD retroiluminada) controlada pelo software NIS elements.

\subsection{Quantificação da fluorescência}

No caso das quantificações de estímulos por EGF, LPA e Insulina, foi quantificado a intensidade de fluorescência da miosina- $\mathrm{V}$ fosforilada no citoplasma das células. Após remover $5 \%$ do background, foi tracejado uma linha em volta do citoplasma da célula e a intensidade de fluorescência indicada pelo ImageJ na região, foi dividida pelo tamanho da área selecionada (célula).

Para a quantificação das proteínas dinamina e clatrina nas adesões focais, foram selecionadas regiões em volta das adesões focais, como demonstrado na figura $16 \mathrm{~B}$, e a intensidade de fluorescência na região das adesões focais foi mesurada no canal da proteína de interesse (clatrina ou dinamina). O programa utilizado para essas análises foi o Particle Analizer (http://www.columbia.edu/ wc2383/software.html). Os testes estatísticos foram realizados pelo programa GraphPad Prism 6.

\subsection{Silenciamento da miosina-Va por siRNA}

Os fibroblastos $3 \mathrm{~T} 3$ foram crescidos em meio normal, com 10\% de BCS e transfectados com $5 \mu \mathrm{L}$ do reagente de transfecção RNAiMAX (Life Technologies) e 20nM da solução de siRNA (para miosina-Va ou do siRNA controle) por poço em placas de 6 poços. Foram seguidas as recomendações do fabricante para a transfeção reversa com lipofectamina, e as células foram silenciadas por $72 \mathrm{~h}$ até o início do tratamento com nocodazol. Sequências de siRNA para miosina-Va foram desenhadas utilizando o website BIOPREDsi (www.biopredsi.org/) e sintetizadas pela Gene Pharma (Shangai, China), como segue:

siMYO5A \#1: 5'-AATATTATCATTCCTGGTTGTCCTGTCTC-3'; siMYO5A \#2: 5'-ATGTCTTACCAAACTGGTATCCTGTCTC-3'.

\subsection{Midi-preparação plasmidial}

Os plasmídeos utilizados neste trabalho foram o MVa-FL-GFP (MVa inteira) e o MVaFT-GFP (cauda inteira da MVa / dominante negativo). Uma alíquota do estoque de bactérias congelado no $-70^{\circ} \mathrm{C}$ foi deixada crescendo em $1 \mathrm{~mL}$ de meio terrific broth (TB) por $1 \mathrm{~h}$ a 200 rpm e $37^{\circ} \mathrm{C}$. Parte deste meio foi inoculado em placa de LB ágar (suplementada com antibiótico seletivo ampicilina) para formação das colônias overnight. Uma colônia de bactérias 
proveniente de placa de cultura fresca foi inoculada em $5 \mathrm{~mL}$ de meio $\mathrm{LB}$, acrescido do antibiótico seletivo ampicilina, e incubada sob agitação de $280 \mathrm{rpm}$, a $37^{\circ} \mathrm{C}$ por $8 \mathrm{~h}$. Em seguida, a cultura foi expandida, inoculando-se $2 \mathrm{~mL}$ do pré-inóculo em $2 \mathrm{~L}$ de meio seletivo, mantendo a incubação nas mesmas condições por mais $14 \mathrm{~h}$. A cultura foi então centrifugada a $6.000 \mathrm{xg}$ por 15 minutos, a $4^{\circ} \mathrm{C}$.

O pellet obtido foi ressuspendido em $125 \mathrm{~mL}$ de tampão de homogenização (Tris-HCl 50mM, pH 8,0; EDTA 10 mM; RNase A $100 \mu \mathrm{g} / \mathrm{mL}$ ) e, em seguida, a lise celular foi promovida com a adição de 125 mL de tampão de lise [NaOH 200 mM; SDS 1\% (m/v)], misturando-se por meio de 6 inversões completas do tubo, seguida de incubação por 5 minutos à temperatura ambiente. Posteriormente, $125 \mathrm{~mL}$ de tampão de neutralização (acetato de potássio $3 \mathrm{M}$, pH 5,5) foram adicionados e, da mesma forma, o tubo foi invertido para a mistura completa. Seguiu-se, então, incubação no gelo por 20 minutos. Após nova inversão do tubo, procedeu-se à centrifugação a $20.000 \mathrm{xg}$, por 30 minutos a $4^{\circ} \mathrm{C}$, de forma que o sobrenadante foi transferido para um novo tubo para ser submetido à nova centrifugação de 15 minutos para total remoção das impurezas. O DNA contido no sobrenadante foi precipitado com isopropanol através de centrifugação a $15.000 \mathrm{xg}$ por 30 minutos. O pellet foi ressuspendido em TE (Tris- $\mathrm{HCl} 10 \mathrm{mM}$ pH 8,0 e EDTA 1mM) e diluído em tampão de equilíbrio [ $\mathrm{NaCl} 750 \mathrm{mM}$; MOPS $50 \mathrm{mM}$, pH 7,0; isopropanol 15\% (v/v); Triton X-100 0,15\% (v/v)].

Enquanto procederam-se as centrifugações, uma coluna Qiagen-Tip 500 foi equilibrada com $10 \mathrm{~mL}$ do tampão de equilíbrio, permitindo a passagem de todo volume por meio do fluxo gerado pela ação da gravidade. Aplicou-se todo o DNA na coluna e, após o gotejamento completo, seguiram-se duas lavagens com $30 \mathrm{~mL}$ de tampão de lavagem [ $\mathrm{NaCl} 1 \mathrm{M}$; MOPS 50 $\mathrm{mM}, \mathrm{pH}$ 7,0; isopropanol 15\% (v/v)]. O DNA plasmidial foi, então, eluído com $15 \mathrm{~mL}$ de tampão de eluição [ $\mathrm{NaCl}$ 1,25 mM; Tris- $\mathrm{HCl} 50 \mathrm{mM}, \mathrm{pH} 8,5$; isopropanol 15\% (v/v)] e, precipitado com a adição de $10,5 \mathrm{~mL}$ de isopropanol à temperatura ambiente que, após a mistura por inversão, foi submetido à centrifugação a $15.000 \mathrm{xg}, 30$ minutos, a $4^{\circ} \mathrm{C}$. O sobrenadante foi descartado e o pellet lavado com $5 \mathrm{~mL}$ de etanol 70\%, procedendo-se uma nova centrifugação, a $15.000 \mathrm{xg}, 15$ minutos, a $4^{\circ} \mathrm{C}$. Então, o pelllet permaneceu secando ao ar por 15 minutos e, finalmente, foi ressuspendido em $150 \mu \mathrm{L}$ de tampão Te (Tris-HCl 10mM pH 8,0 e EDTA $0,1 \mathrm{mM})$. 


\subsection{Transfecção de Plasmídeos}

Os fibroblastos 3T3 foram crescidos em meio normal, com 10\% de BCS e transfectados com $5 \mu \mathrm{L}$ do reagente de transfecção Lipofectamina 2000 (Life Technologies) e 2500ng de DNA por poço em placas de 6 poços. Foram seguidas as recomendações do fabricante para a transfeção lipofectamina 2000.

\subsection{Anticorpos primários e secundários utilizados neste trabalho}

- 9E6 (anti p-miosina-Va), (Pranchevicius, 2008), utilizado na diluição 1:50;

- Cauda Medial (anti miosina-Va total), (Bizário et al., 2002), utilizado na diluição 1:100;

- Anti cabeça (anti miosina-Va total), produzido em nosso laboratório na diluição 1:50;

- pFAK (Invitrogen \#44624G), utilizado na diluição 1:100;

- Vinculina (Sigma \#V4139), utilizado na diluição 1:100;

- Dinamina-2 (abcam \#ab3457), utilizado na diluição 1:100;

- Anticorpo donkey anti-IgG de coelho conjugado com Alexa 488 (Molecular Probes), utilizado na diluição 1:300;

- Anticorpo donkey anti-IgG de coelho conjugado com Alexa 594 (Molecular Probes), utilizado na diluição 1:300;

- Anticorpo donkey anti-IgG de camundongo conjugado com Alexa 488 (Molecular Probes), utilizado na diluição 1:300;

- Anticorpo donkey anti-IgG de comundongo conjugado com Alexa 594 (Molecular Probes), utilizado na diluição 1:300;

- Anticorpo donkey anti-IgG de camundongo conjugado com Alexa 633 (Life Technologies \#A21070), utilizado na diluição 1:300;

- Anticorpo policlonal de cabra anti IgG de camundongo conjugado a HRP (Horse Radish Peroxidase, Promega), utilizado na diluição de 1:2.000;

- Anticorpo policlonal de cabra anti IgG de coelho conjugado a HRP (Horse Radish Peroxidase, Promega), utilizado na diluição de 1:10.000; 


\section{Resultados}

\subsection{EGF, Insulina e LPA induzem a fosforilação da miosina-V}

Resultados prévios, obtidos durante o mestrado, demonstraram que o estímulo por soro fetal bovino (SFB) induz a fosforilação da miosina-V em células quiescentes e a localização da miosina-V nas AFs. Para elucidar melhor qual componente do soro estaria induzindo a fosforilação da miosina- $\mathrm{V}$, decidimos estimular as células com componentes específicos do soro, como EGF, ácido lisofosfatídico (LPA) e insulina, para determinar assim o efeito de cada um deles sobre a fosforilação e localização celular da miosina-V. O procedimento foi feito seguindo o protocolo de estímulo por soro, onde as células foram plaqueadas e privadas de soro por $48 \mathrm{~h}$, e então estimuladas com os respectivos componentes por até 30 minutos. Após o estímulo, analisou-se as imagens das células fixadas para determinar o grau de fosforilação e a distribuição subcelular da miosina-V.

O primeiro componente que testamos foi o EGF, o qual participa da via de sinalização de Grab2 (ODA et al., 2005). O estímulo por EGF induziu um rápido aumento na marcação de miosina-V fosforilada, após 5 minutos já foi possível perceber esse aumento da miosina-V fosforilada no citoplasma da célula (Figura 3 e 6), uma vez que já demonstramos durante meu mestrado que o soro induz apenas um aumento na miosina- $\mathrm{V}$ fosforilada e não na quantidade total de miosina-V no citoplasma. E assim como visto pelo estímulo com soro, houve uma queda na quantidade de miosina-V fosforilada após 30 minutos. Houve também uma visível redistribuição da miosina-Va nas células estimuladas por EGF, mas o estímulo por EGF não induziu a montagem das adesões focais ou alguma mudança significativa na distribuição celular de vinculina (Figura 3).

O próximo passo foi testar a insulina, percebemos que o estímulo por insulina também induziu um aumento na marcação de miosina- $\mathrm{V}$ fosforilada, e assim como o EGF, induziu uma redistribuição da miosina- $\mathrm{V}$ após 5 e 15 minutos, onde a miosina- $\mathrm{V}$ se redistribuiu em direção a periferia da célula. Após 15 minutos de estímulo por insulina houve um aumento da miosina$\mathrm{V}$ fosforilada na célula, a qual parece se acumular em pequenos agrupamentos próximos da membrana celular (Figura 4 e 6), e assim como no estímulo por soro e EGF, houve um decaimento na miosina-V fosforilada após 30 minutos. 


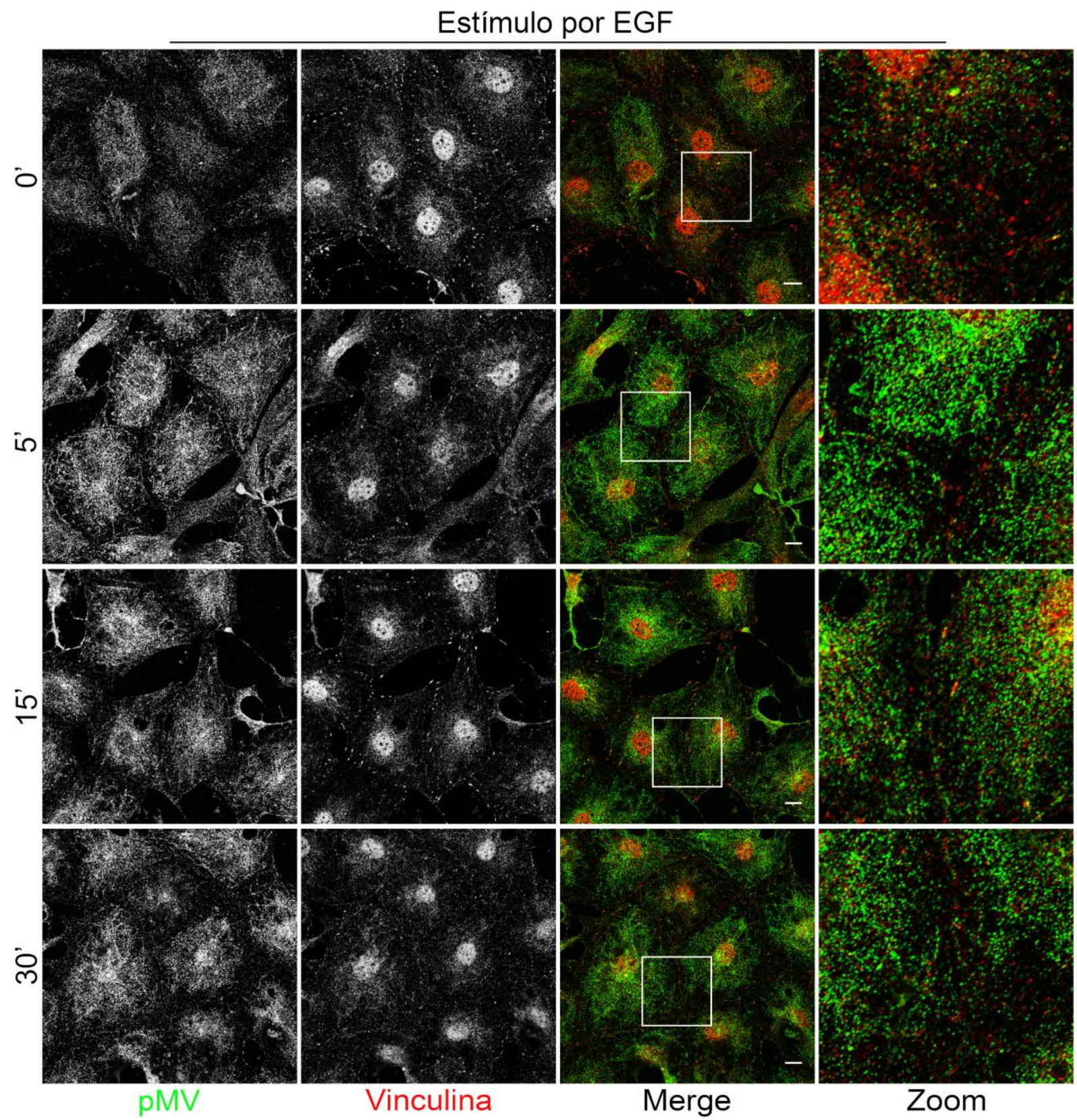

Figura 3: Estímulo por EGF induz a fosforilação da miosina-V. Imagens de microscopia confocal. Células NIH 3T3 foram privadas de soro por 48h e então estimuladas com 10 $\mu$ g de EGF por 5, 15 e 30 minutos e marcadas para miosina- $\mathrm{V}$ fosforilada (verde) e para vinculina (vermelho), o tempo 0 mostra as células antes do estímulo. $\mathrm{n}=$ 3 experimentos independentes Barra de escala: $10 \mu \mathrm{m}$. 


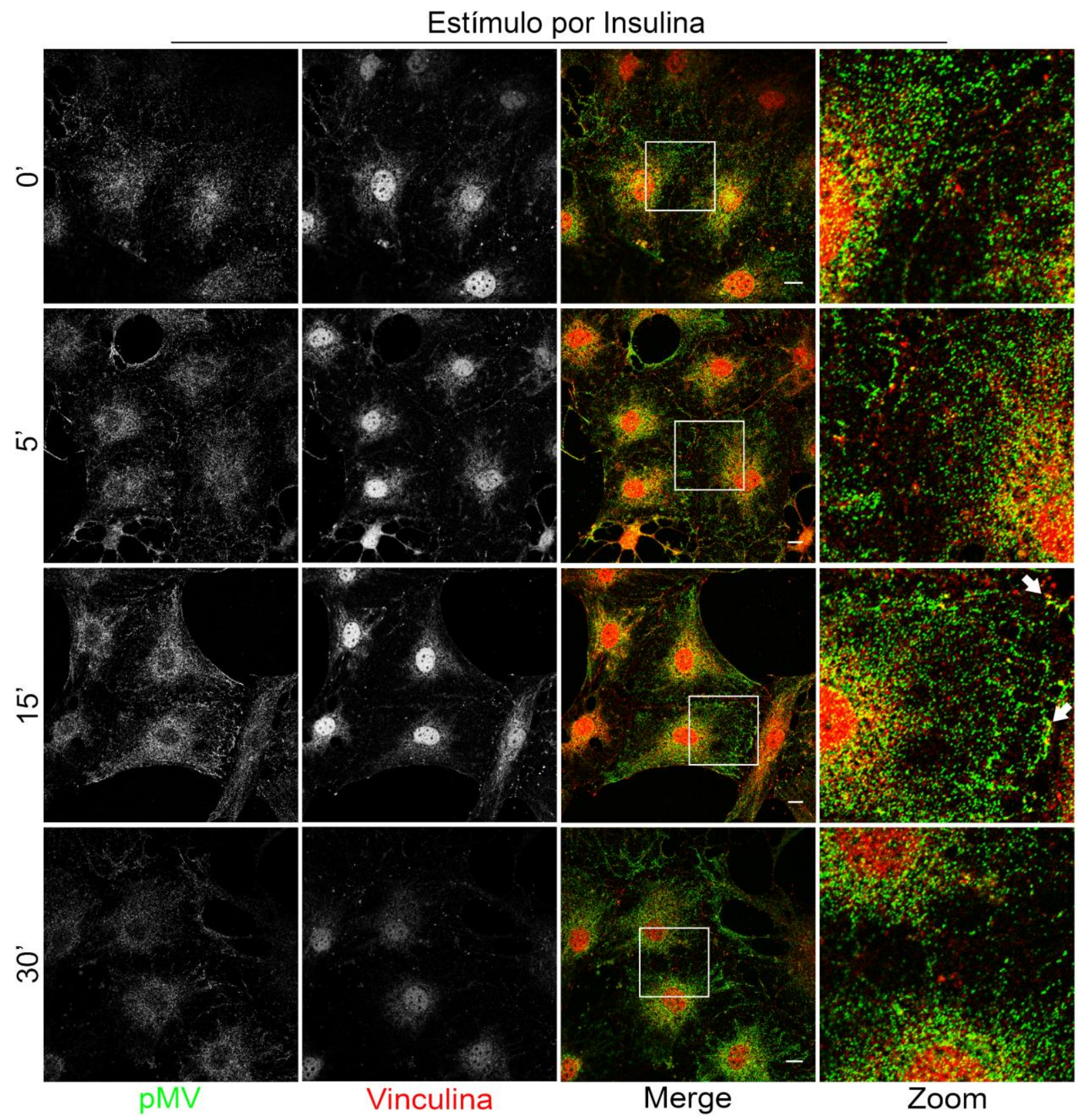

Figura 4: Estímulo por insulina induz a fosforilação da miosina-V. Imagens de microscopia confocal. Células NIH 3 T3 foram privadas de soro por 48h e então estimuladas com $100 \mathrm{~nm}$ de insulina por 5, 15 e 30 minutos e marcadas para miosina- $\mathrm{V}$ fosforilada (verde) e para vinculina (vermelho), o tempo 0 mostra as células antes do estímulo. Há um acúmulo peculiar de pMVa próxima da borda celular após 15 minutes de estímulo (setas brancas). $\mathrm{n}=4$ experimentos independentes Barra de escala: $10 \mu \mathrm{m}$. 
Testamos também o ácido lisofosfatídico (LPA) - componente do soro responsável por induzir a formação das AFs em células quiescentes (RIDLEY; HALL, 1992). O estímulo por LPA, induziu tanto a fosforilação da miosina-V quanto a montagem das adesões focais (Figura 5 e 6). Também foi possível observar uma redistribuição da miosina-V neste caso, e a miosina$\mathrm{V}$ pareceu se acumular em pequenos agrupamentos próximos a periferia da célula, assim como no estímulo por EGF. Mais interessante ainda, que no caso do LPA, esses agrupamentos se colocalizam com as AFs (Figura 5). O LPA teve um resultado semelhante aos resultados obtidos com estímulo por soro, em que o estímulo por soro induz a fosforilação e a localização da miosina-V nas AFs. Notamos também que no estímulo por LPA, ocorre uma redução da marcação de miosina- $\mathrm{V}$ fosforilada no citoplasma da célula após 30 minutos de estímulo, assim como nos estímulos por soro, EGF e Insulina. Embora o LPA tenha reproduzido um resultado muito próximo do obtido pelo estímulo com soro, a fosforilação da miosina-V também é induzida pelos estímulos com Insulina e EGF. Juntos esses resultados demonstram que há mais de um componente do soro que induzem a fosforilação da miosina- $\mathrm{V}$, a qual pode se dar por diferentes vias de sinalização em cada um dos casos. 


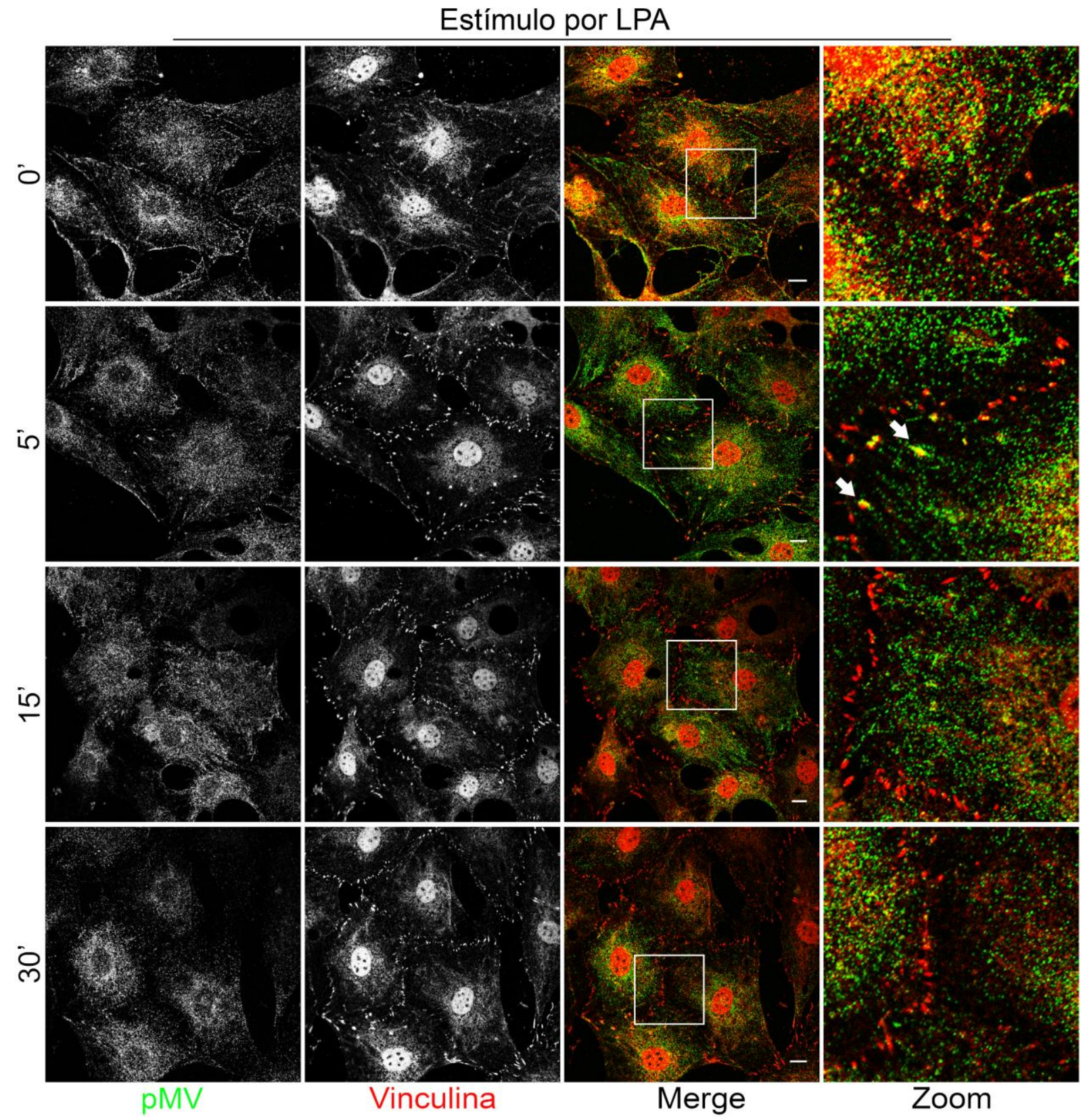

Figura 5: Figura 4: Estímulo por LPA induz a montagem das adesões focais e a fosforilação da miosina-V. Imagens de microscopia confocal de células NIH 3T3, as células foram privadas de soro por $48 \mathrm{~h}$ e então estimuladas com 100ng/ml de ácido lisofosfatídico (LPA) por 5, 15 e 30 minutos e marcadas para miosina-V fosforilada (verde) e para vinculina (vermelho). O tempo 0 mostra as células antes do estímulo. É possível observar a colocalização de pMVa e Vinculina nas adesões focais (setas brancas). $n=4$ experimentos independentes Barra de escala: $10 \mu \mathrm{m}$. 


\section{EGF}

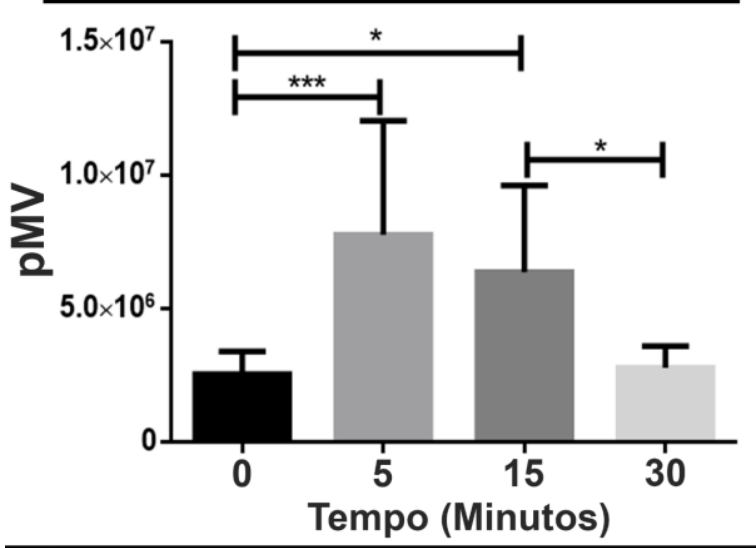

\section{Insulina}

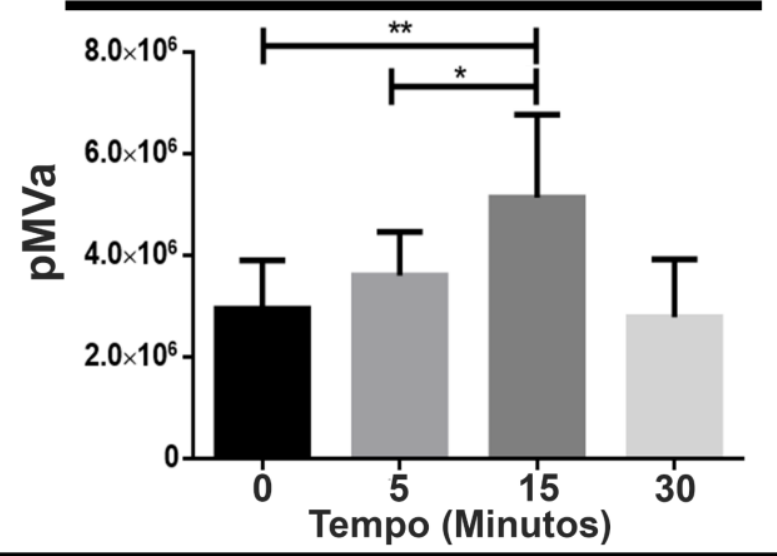

\section{LPA}

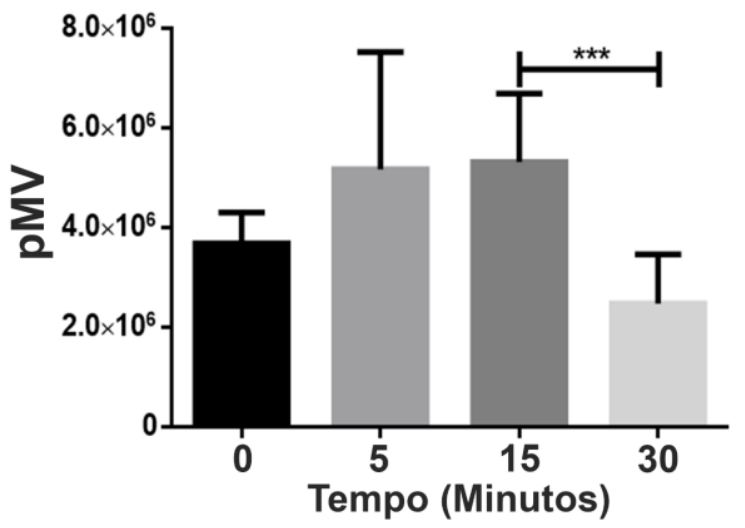

Figura 6: EGF, Insulina e LPA induzem a fosforilação da miosina-V. Quantificação da fluorescência em células NIH3T3, através do ImageJ, da miosina-V fosforilada (pMV) ao passar do tempo, na quiescência ( $0^{\prime}$ ) e passados 5', 15', 30' e 120' minutos após o estímulo. $\mathrm{n}=$ quantificadas pelo menos 20 células em cada experimento, e realizados 3 experimentos independentes. 
Com esse aumento da fosforilação da miosina-V concomitante com a formação das AFs induzidas pelo estimulo com soro e LPA, e sabendo que o silenciamento da miosina-Va afeta a migração celular (LAN et al., 2010), nos perguntamos se a miosina-Va participa da montagem das adesões focais. Para responder esta pergunta, decidimos analisar a montagem das AFs após estímulo por soro, e utilizamos a técnica de siRNA para silenciar a miosina-Va. Nosso silenciamento da MVa teve uma eficácia de 65 a 80\%, reduzindo a expressão proteica de MVa nas células silenciadas (Figura 7A e 7B).
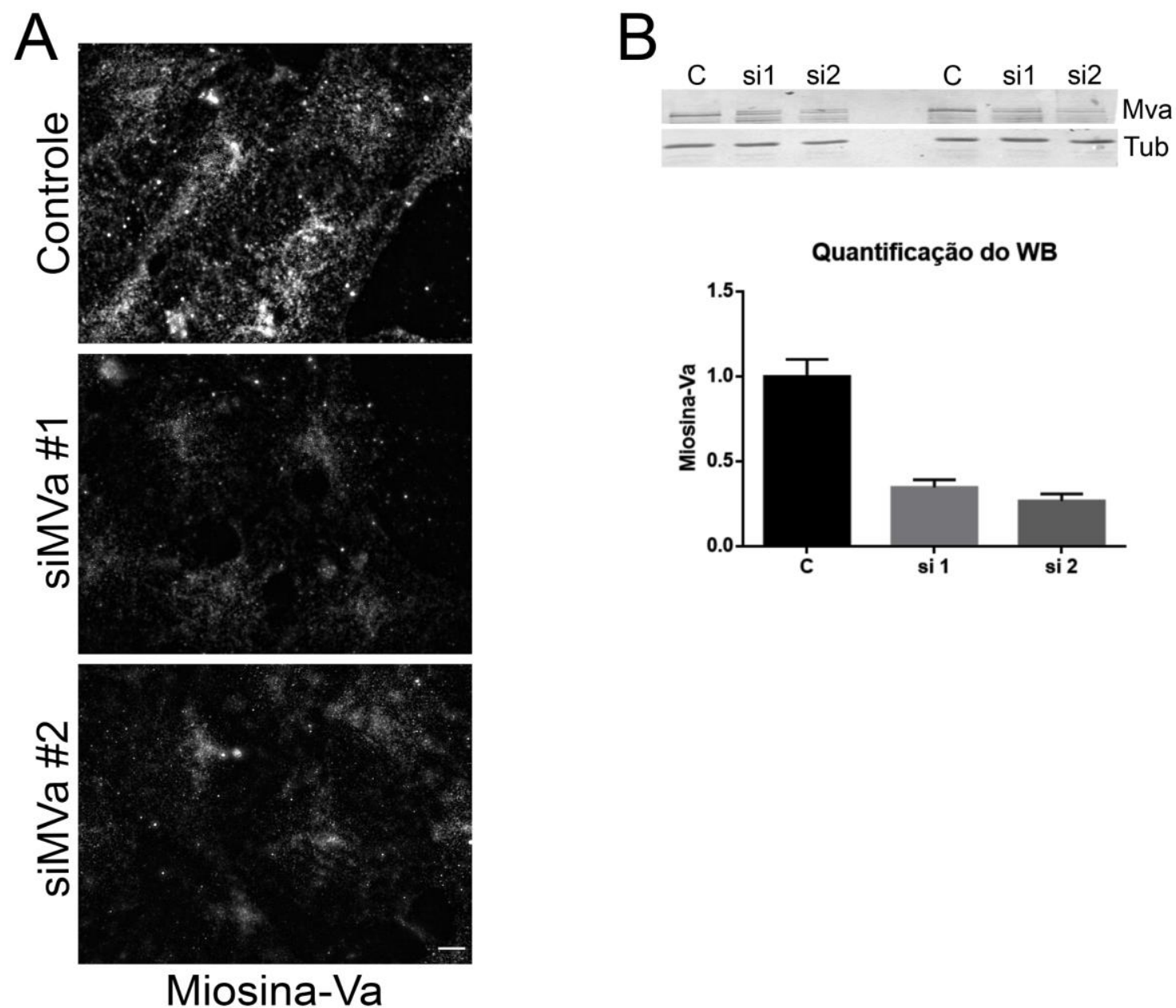

Figura 7: Silenciamento da miosina-Va. As células foram silenciadas com siRNA controle e dois siRNAs para MVa por 72h. A) Imunofluorescência da MVa total (anti-cabeça), comparando os diferentes siRNAs. Barra de

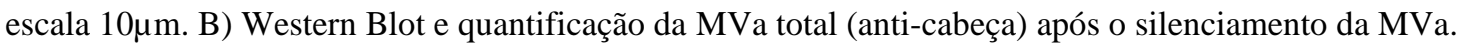


Procuramos então, analisar como se dava a montagem das adesões focais em células quiescentes após estímulo por soro. As células foram privadas de soro por $48 \mathrm{~h}$ e então estimuladas com soro (DMEM suplementado com 10\% de soro). As células no tempo 0, são células quiescentes e que não possuem adesões focais, e foi possível perceber uma rápida montagem das adesões focais, apenas 15 minutos após o estímulo, tanto nas células controle (Figura 8, cima) quanto nas silenciadas para MVa (Figura 8, baixo). Deste modo a miosina-Va parece não afetar a formação das AFs ou interferir na localização da pFAK nas AFs, que ocorrem normalmente nas células silenciadas e com tempo similar ao das células controle, e nossos dados sugerem que a montagem das adesões focais induzidas por soro se dá de maneira independente da miosina-Va. Como o anticorpo 9E6 reconhece as 3 isoformas da miosina-V (MVa, MVb, MVc) não se percebeu uma diminuição clara da fluorescência de miosina-V fosforilada nas células. 

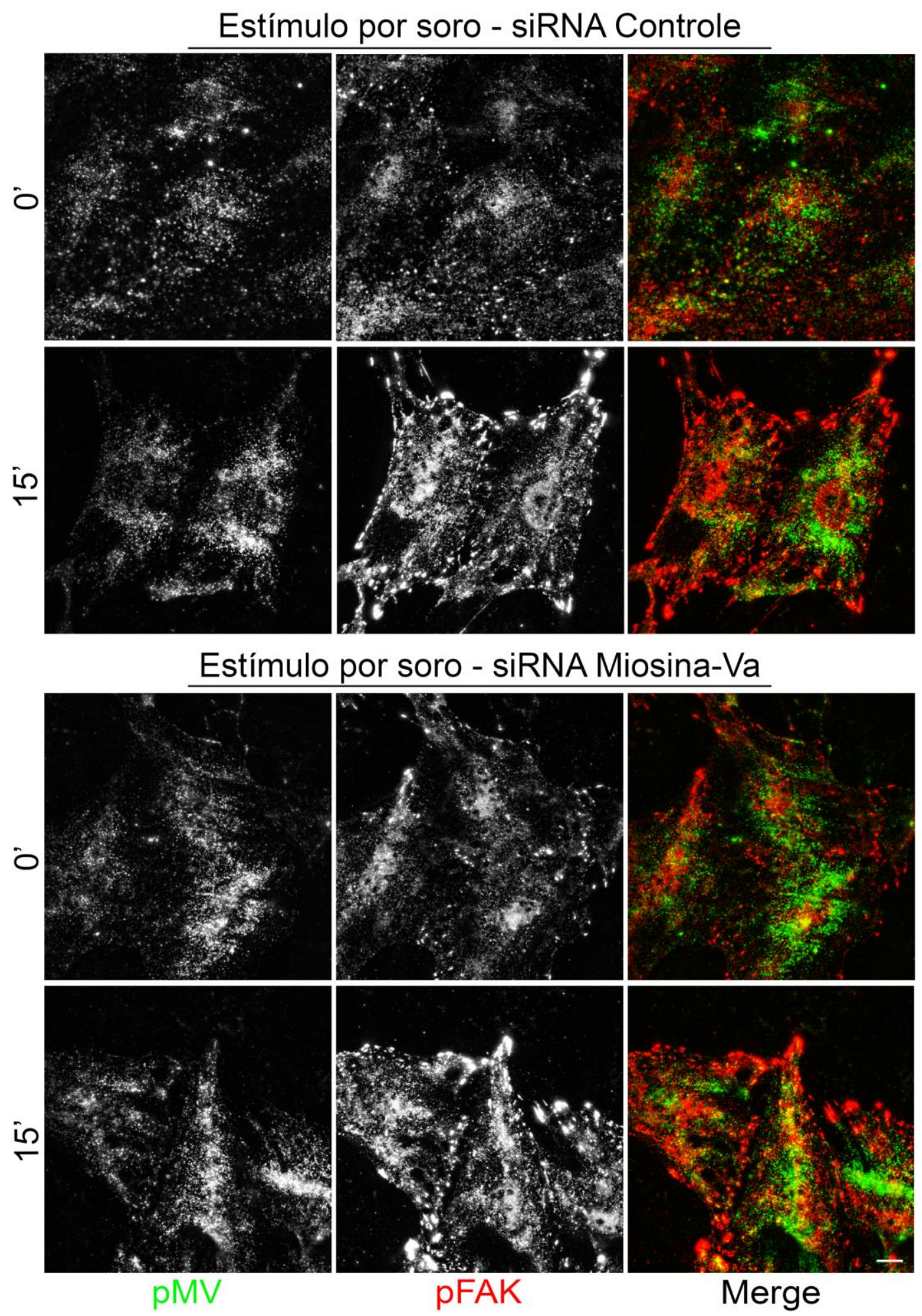

Figura 8: O silenciamento da MVa não afeta a montagem das adesões focais após estímulo por soro. As células foram silenciadas com siRNA controle e dois siRNAs independentes para miosina-Va. Imagens de microscopia TIRF (Total Internal Reflection Fluorescence microscope) mostram a miosina-V fosforilada (verde) e a FAK-Y397 (vermelha). É possível observar que as adesões focais se formam normalmente nas células silenciadas, não sendo possível detectar um atraso considerável no tempo de formação das adesões e no tamanho das AFs. $n=3$ experimentos independentes. Barra de escala $10 \mu \mathrm{m}$. 


\subsection{A miosina-V se localiza nas adesões focais após tratamento por nocodazol}

Uma vez que a MVa não afetou a montagem das AFs, começamos a analisar se a MVa participaria da desmontagem, para isso seguimos o protocolo descrito por Ezratty et al., 2005, que consistem em privar as células de soro por $48 \mathrm{~h}$ e adicionar nocodazol ao meio por 3-4h (Nocodazole Washout assay). O nocodazol irá despolimerizar os microtúbulos e quando o nocodazol é retirado do meio, as AFs se desmontam de forma conjunta, organizada e sincronizada, permitindo assim analisar como acontece a desmontagem das AFs e as proteínas envolvidas neste processo.

O targeting dos microtúbulos nas AFs induz sua desmontagem (EZRATTY; PARTRIDGE; GUNDERSEN, 2005), de maneira que as AFs começam a serem desmontadas logo após a "chegada" microtúbulos. Utilizamos o mesmo protocolo para ver se a miosina-Va se localiza nas AFs e se o silenciamento da MVa afeta a desmontagem. Primeiramente queríamos analisar a localização da miosina-V fosforilada nas AFs após tratamento com nocodazol, para isso realizamos a imunofluorescência das células após o tratamento e as imagens foram feitas em diferentes microscópios. No microscópio confocal temos uma boa definição da imagem, mas a fatia mínima desse microscópio acaba sendo grande e uma colocalização entre imagens nem sempre é real, onde as imagens podem parecer estar juntas, mas na verdade estão apenas próximas e não há interação entre elas. Pela microscopia confocal podemos analisar que não há um aumento na fosforilação da miosina-V após nocodazol e não é possível perceber uma grande localização da miosina-V nas adesões focais (Figura 9), o que pode ser devido ao baixo sinal da miosina- $\mathrm{V}$ fosforilada nas células, uma vez que sem o aumento da fosforilação o sinal da proteína se mantem baixo. A miosina-V fosforilada parece estar distribuída por todo o citoplasma da célula nos tempos 0', 10', 60', 90' e após 120'de estímulo parece haver uma queda na marcação da fluorescência de miosina- $\mathrm{V}$ fosforilada.

Para analisar melhor essa localização da miosina-V nas adesões focais, utilizamos microscopia SIM (structured illuminated microscopy), que proporciona uma melhor resolução das imagens. Através da microscopia SIM é possível perceber a presença da MVa nas AFs (Figura 10), onde a miosina-V fosforilada pode ser vista nas adesões focais principalmente no tempo 0', onde se é possível perceber estruturas similares a adesões focais já no canal da miosina- $\mathrm{V}$, e quando sobrepostas as imagens de FAK mostram uma colocalização interessante entre as duas proteínas. 


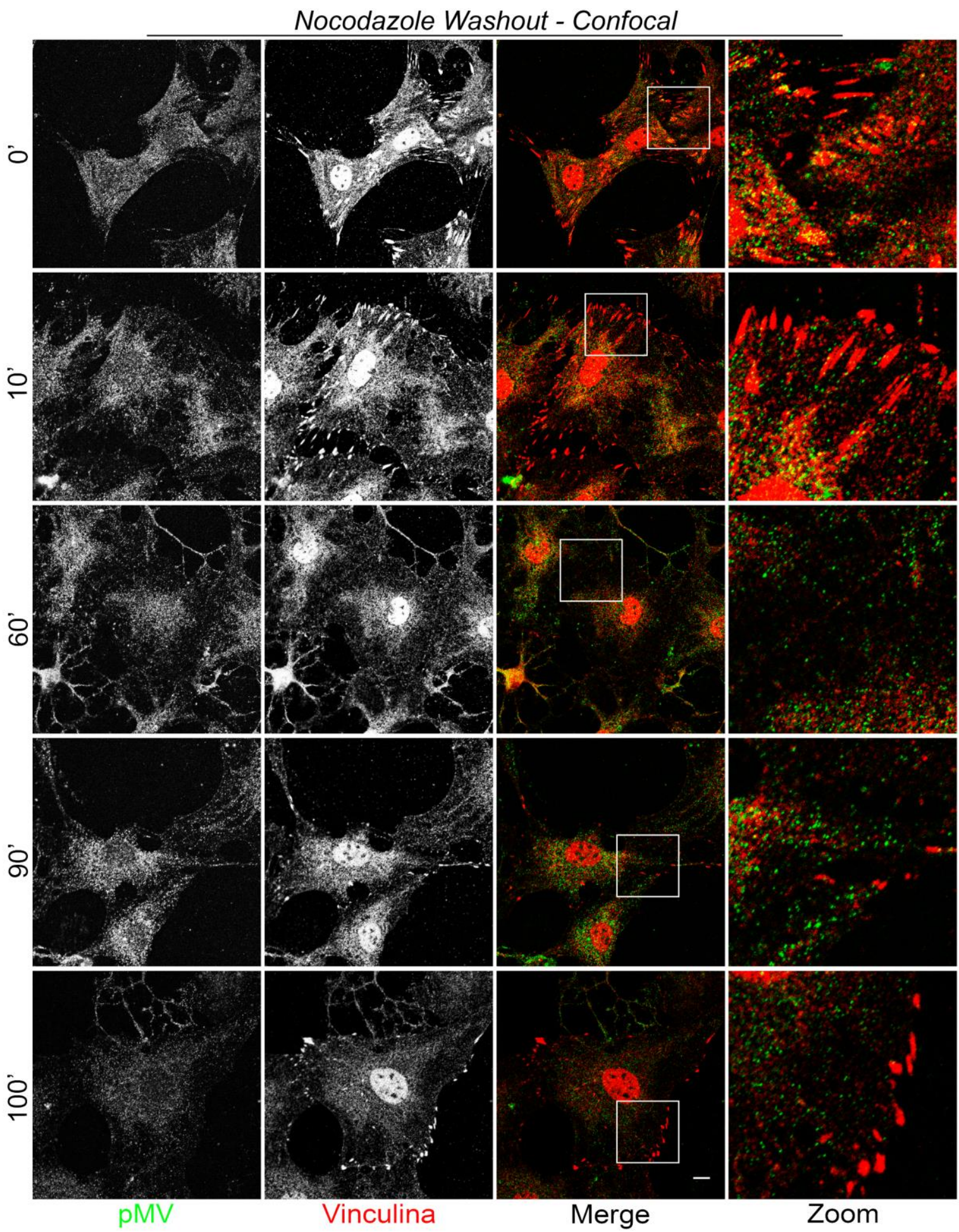

Figura 9: A miosina-V fosforilada se localiza nas adesões focais após tratamento com nocodazol. Imagens de microscopia confocal após tratamento por nocodazol em células NIH 3T3, as células são privadas de soro por 48h, tratadas com nocodazol por 3-4h e então fixadas nos tempos 0 e 10, 60, 90 e 100 minutos após a lavagem do nocodazol. Não há um aumento da fosforilação da miosina-Va (verde) após a lavagem do nocodazol, e a desmontagem das adesões focais (vinculina em vermelho) ocorre como descrito na literatura, onde as AFs são completamente desmontas após 60 minutos da lavagem e começam a retornar aproximadamente 90 minutos após a lavagem. Barra de escala $10 \mu \mathrm{m}$. 


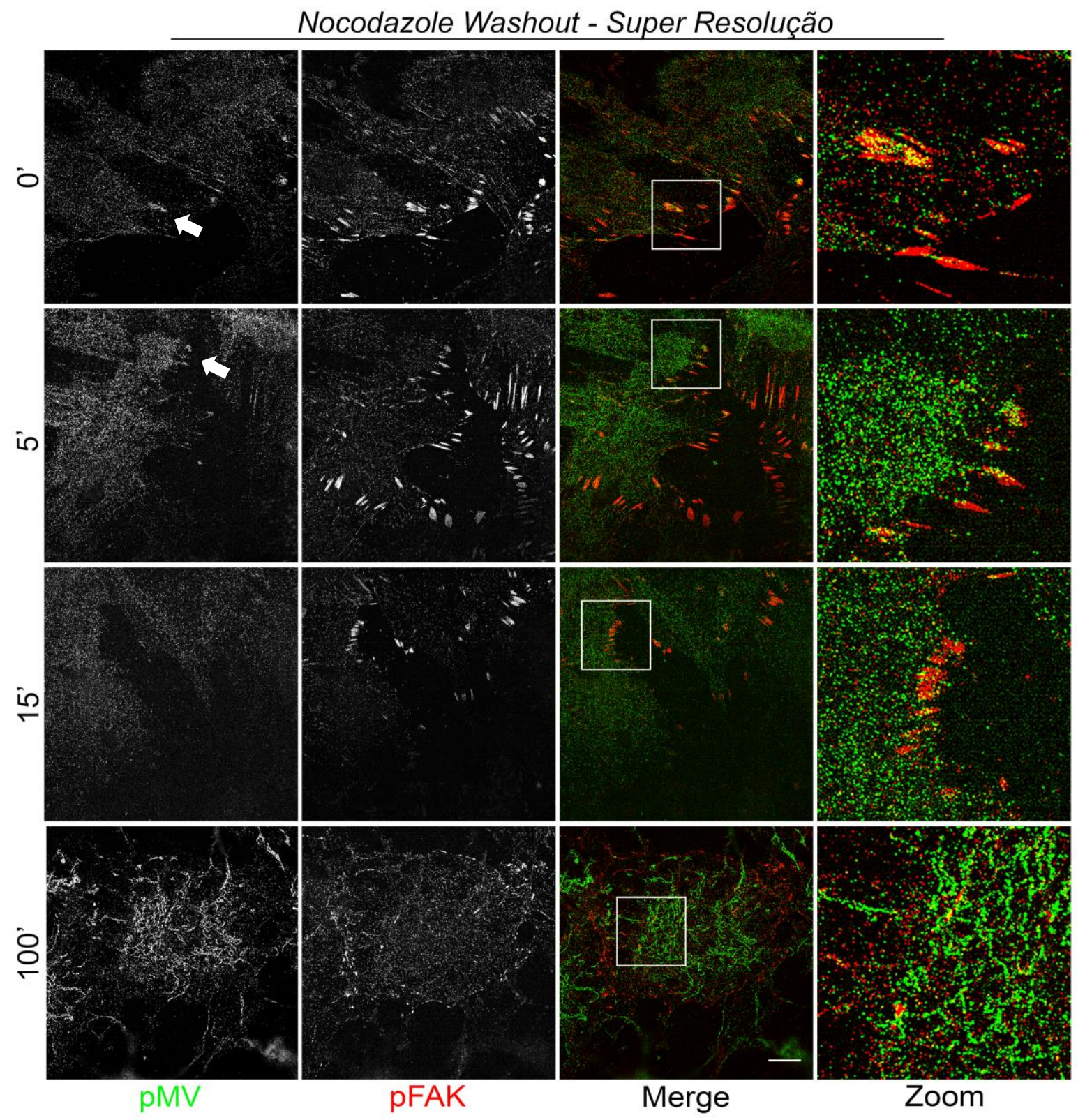

Figura 10: A miosina-V fosforilada se localiza nas adesões focais após tratamento com nocodazol. Imagens de microscopia de SIM (structured illuminated microscopy) após tratamento por nocodazol em células NIH 3T3, as células foram fixadas nos tempos 0 (3-4h de tratamento com nocodazol) e 5, 15 e 100 minutos após a lavagem do nocodazol. Não é perceptível um aumento da fosforilação da miosina-Va (verde) após a lavagem do nocodazol. É possível perceber uma colocalizaçao da miosina- $\mathrm{V}$ fosforilada nas adesões focais (pFAK em vermelho) nos tempos 0, 5 e 15 minutos após a lavagem do nocodazol, e há uma distribuição citoplasmática interessante da miosina-V 100 minutos após a lavagem. Estruturas semelhantes a adesões focais no canal da miosina-V fosforilada (flechas brancas). $\mathrm{n}=1$ experimento. Barra de escala $10 \mu \mathrm{m}$. 
Cinco minutos após a lavagem do nocodazol ainda é possível perceber algumas estruturas semelhantes a adesões focais no canal da miosina- $\mathrm{V}$ fosforilada embora a colocalização com pFAK diminua um pouco, após 15 minutos da lavagem a colocalização entre as duas proteínas ainda existe nas AFs, mas não é mais possível perceber estruturas semelhantes a AFs no canal da miosina. Após 100 minutos da lavagem, que é quando se dá uma alta taxa da remontagem das adesões focais (EZRATTY et al., 2005), é possível perceber uma redistribuição peculiar da miosina-V fosforilada através da microscopia SIM. As adesões focais são bem visíveis e após 10-15 minutos da lavagem do nocodazol começam a ser desmontadas, e após 100 minutos da lavagem começam a ser remontadas, como já descrito na literatura.

A microscopia TIRF (Total Internal reflection Fluorescence microscope) permite uma visão de alta resolução, mas de baixa penetração na célula, tornando visível apenas uma fina faixa próxima a membrana plasmática, e apenas proteínas nessa faixa ficam visíveis (FISH, 2009). Essa microscopia é a mais indicada para o estudo das AFs, uma vez que não detecta proteínas que estão mais afastadas da membrana plasmática, permitindo uma visão mais limpa e precisa das proteínas associadas as AFs. Novamente não é possível se perceber uma diferença na montagem das AFs com o silenciamento da MVa, uma vez que as células controle e silenciadas possuem quantidade e tamanho semelhantes de adesões, mas da mesma maneira como visto pela microscopia SIM, é possível perceber uma colocalização entre miosina-V fosforilada e FAK (Figura 11). Antes da lavagem do nocodazol, tempo 0', a miosina-V fosforilada parece estar associada as AFs e continua 5 minutos após a lavagem do nocodazol, já 15 minutos após a lavagem parece haver uma diminuição da miosina-V fosforilada próxima da membrana plasmática. 100 minutos após a lavagem, quando as AFs começam a ser remontadas, a miosina- $\mathrm{V}$ fosforilada ainda não aparece próxima da membrana plasmática da mesma maneira como nos tempos iniciais.

Juntos esses dados mostram que a miosina-V se localiza nas adesões focais após tratamento com nocodazol, e pode estar participando da dinâmica das AFs, uma vez que parece não afetar a montagem, pode estar participando da desmontagem das AFs. Para elucidar isto, realizamos o silenciamento da miosina-Va e analisamos se a desmontagem, após tratamento por nocodazol, ocorre de maneira normal. 


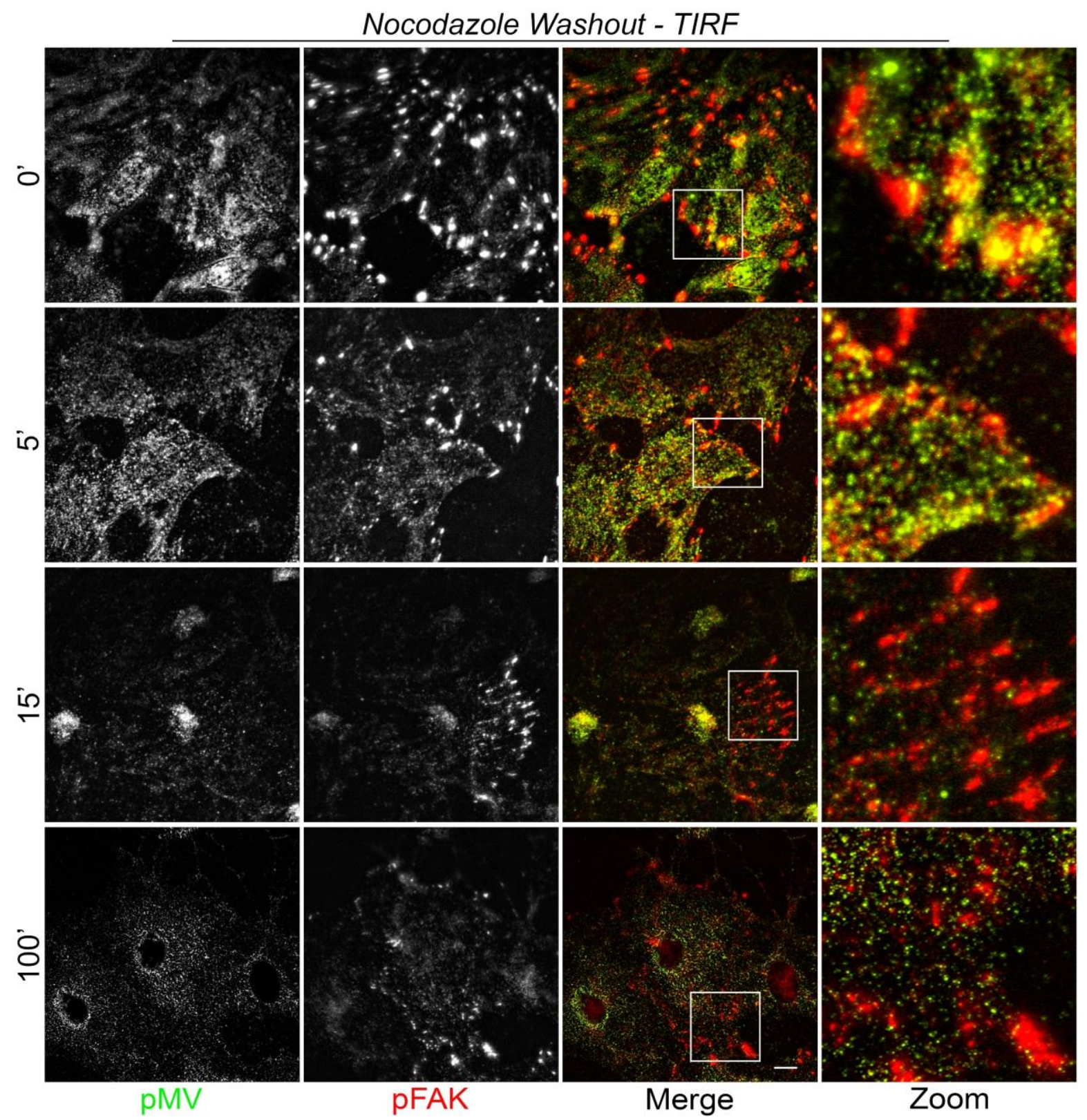

Figura 11: A miosina-Va se localiza nas adesões focais após tratamento com nocodazol. Imagens de microscopia TIRF (Total Internal Reflection Fluorescence microscope) em células NIH3T3 após tratamento por nocodazol em células NIH 3T3, as células foram fixadas nos tempos 0 e 5, 15 e 100 minutos após a lavagem do nocodazol. A análise da fosforilação da miosina-Va (verde) se torna mais complicada nesse tipo de microscopia, uma vez que apenas proteínas próximas a membrana plasmática são detectadas. Já o estudo da dinâmica das adesões focais (pFAK em vermelho) é ideal neste tipo de microscopia, e confirma que a miosina-V fosforilada realmente está localizada muito próxima da membrana plasmática. $n=3$ experimentos independentes. Barra de escala $10 \mu \mathrm{m}$. 


\subsection{A miosina-Va participa da desmontagem das adesões focais}

Para analisar a desmontagem das AFs reproduzimos o tratamento de nocodazol em células controle e silenciadas para miosina-Va. As AFs se desmontam completamente 60 minutos após a lavagem do nocodazol nas células controle, e o silenciamento da miosina-Va não interfere na montagem das adesões após tratamento com nocodazol, mas dificulta a desmontagem completa das AFs 60 minutos após a lavagem (Figura 12).

As AFs remanescentes 60 minutos após a lavagem são ligeiramente menores que as do tempo 0', e interessantemente a maioria das AFs que não desmontam nas células silenciadas estão mais localizas na periferia da célula. É possível perceber a presença da MVa nas adesões focais das células controle, assim como demonstrado anteriormente com a marcação do anticorpo para miosina- $\mathrm{V}$ fosforilada, essa presença diminui consideravelmente nas células silenciadas, uma vez que o sinal da MVa nas células também é menor.

De 40 a 50\% das adesões focais não são desmontadas nas células silenciadas para MVa, onde o número total de AFs passa de uma média de 40, após tratamento com nocodazol, para uma média de 5 adesões por célula, nas células controle. Já nas células silenciadas esse número cai para 15-20 adesões focais por célula, 60 minutos após a lavagem (Figura 13A).

Para entender melhor como a miosina-Va afeta a desmontagem das AFs, realizamos vídeo microscopia TIRF de células expressando Paxilina-GFP. Após 3h de tratamento com nocodazol, o nocodazol foi removido do meio e começamos a fazer as imagens, após 5 minutos da lavagem a intensidade das adesões focais já começou a diminuir e foi possível perceber que elas começaram a ser desmontadas. Nas células controle, após 60 minutos restaram poucas ou nenhuma $\mathrm{AF}$, as quais começaram a ser remontadas entre 90 e 100 minutos após a lavagem do nocodazol. As primeiras AFs foram remontadas na periferia da célula (100-120 minutos), como já descrito por Nader, Ezratty e Gundersen, 2016. Com o silenciamento da MVa essa desmontagem é falha e embora as AFs comecem a desmontar após 5 minutos, há AFs remanescentes após 60 minutos da lavagem, as quais persistem mesmo após 120 minutos (Figura 13B). Embora algumas novas AFs apareçam ao longo do vídeo, as AFs parecem não serem remontadas após 120 minutos, uma vez que boa parte delas não desmontou. 

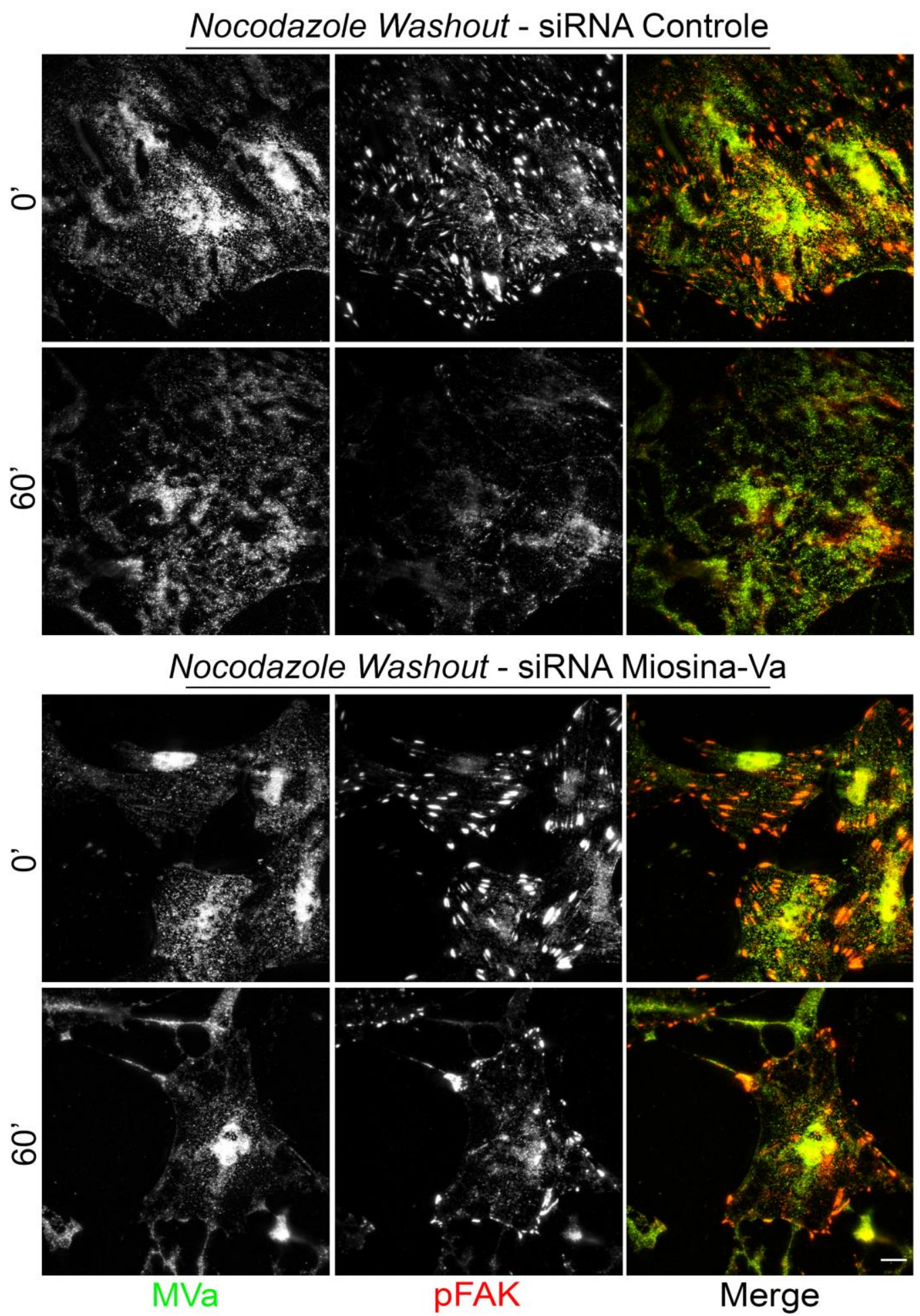

Figura 12: O silenciamento da miosina-Va afeta a desmontagem das adesões focais. Microscopia TIRF de celulas NIH 3T3 controle (cima) e silenciadas para MVa (baixo) após tratamento com nocodazol. As células foram fixadas no tempo 0 e 60 minutos após a lavagem do nocodazol. Nas células transfectadas com o siRNA controle a desmontagem das adesões focais (pFAK, vermelho) ocorre de maneira normal, já nas células transfectadas com siRNA para miosina-Va, a desmontagem das adesões focais não é completa e embora diminua o tamanho e número das adesões focais, a célula perde a habilidade de desmontar corretamente todas as adesões focais. Marcação da miosina-Va em verde. $\mathrm{n}=5$ experimentos independentes. Barra de escala $10 \mu \mathrm{m}$. 


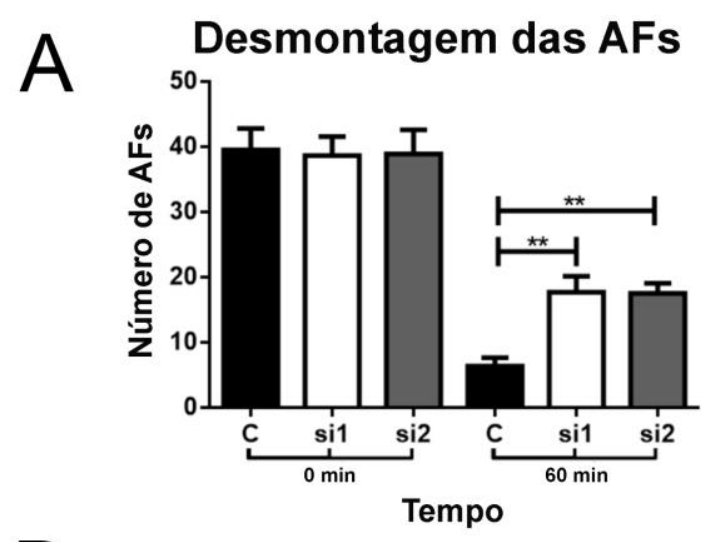

B

Nocodazole Washout - Controle
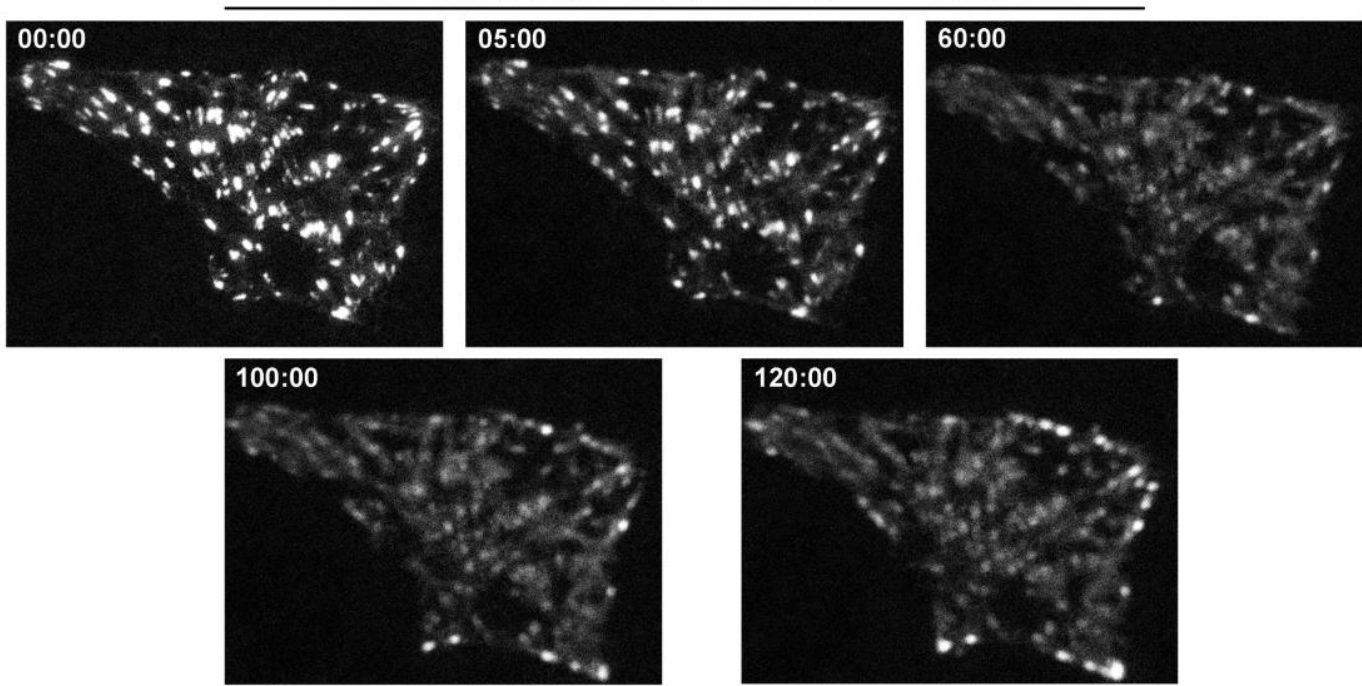

Nocodazole Washout - siRNA MVa

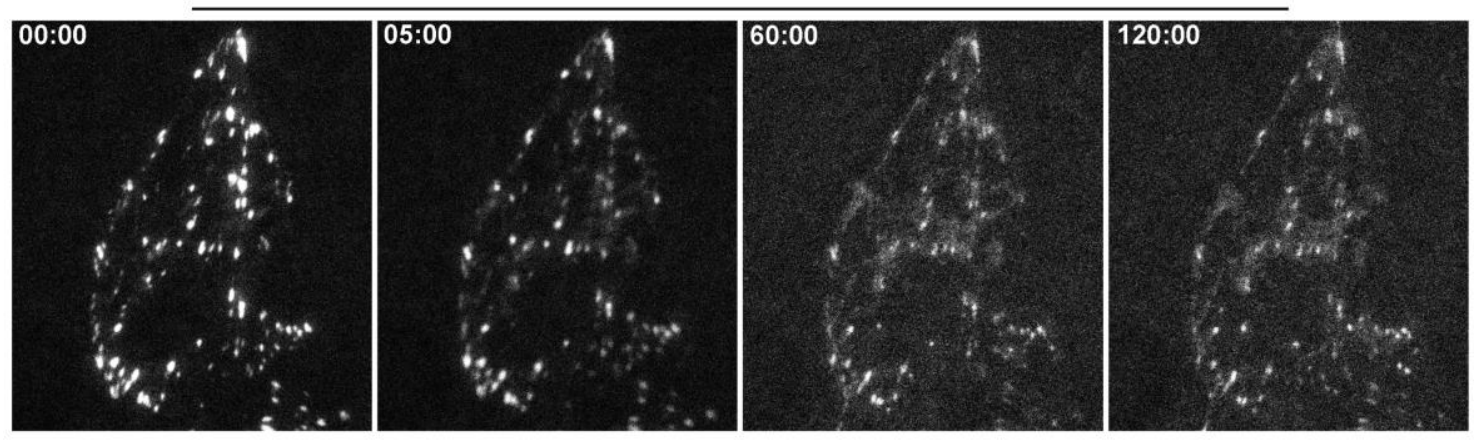

Figura 13: A miosina-Va é importante para a desmontagem das adesões focais. A) Quantificação do número de adesões focais em células NIH 3T3 no tempo 0 e 60 minutos após a lavagem do nocodazol. De 40 a 50\% das adesões focais não desmontam nas células silenciadas para miosina-Va, onde após 60 minutos ainda restam em média 15-20 adesões focais por célula, em contraste com as células controle que após 60 minutos restam de 0 a 5 adesões focais por célula. Foram quantificadas pelo menos 200 AFs por experimento, e foram realizados 3 experimentos independentes. B) Vídeo-microscopia (TIRF) de células NIH-3T3 expressando paxilina-GFP e silenciadas para miosina-Va, assim como nas células fixadas, as células vivas mostram um defeito na desmontagem das adesões focais, quando comparamos as células controle (cima) com as células silenciadas (baixo). 
Ainda, para confirmar o papel da MVa na desmontagem das AFs, o ensaio foi repetido utilizando células transfectadas com a cauda inteira da MVa, a qual funciona como um dominante negativo da MVa, pois contém a região que se liga a carga, mas não contém a região da cabeça a qual se liga a actina. A expressão da MVa-FT (MVa-cauda inteira / full tail) não interferiu na montagem das AFs após tratamento com nocodazol, mas assim como o silenciamento da MVa, também dificulta a desmontagem completa das AFs 60 minutos após a lavagem do nocodazol (Figura 14).

Nas células expressando apenas GFP a dinâmica das AFs ocorre de forma normal após o tratamento com nocodazol, já nas células expressando a cauda inteira da MVa além da desmontagem ser defeituosa há uma forte colocalização da MVa-FT nas AFs após o tratamento e 60 minutos após a lavagem do nocodazol, e pode ser percebido estruturas semelhantes a AFs no canal do GFP nas células expressando a cauda inteira da miosina (Figura 14, baixo). 
Nocodazole Washout - GFP
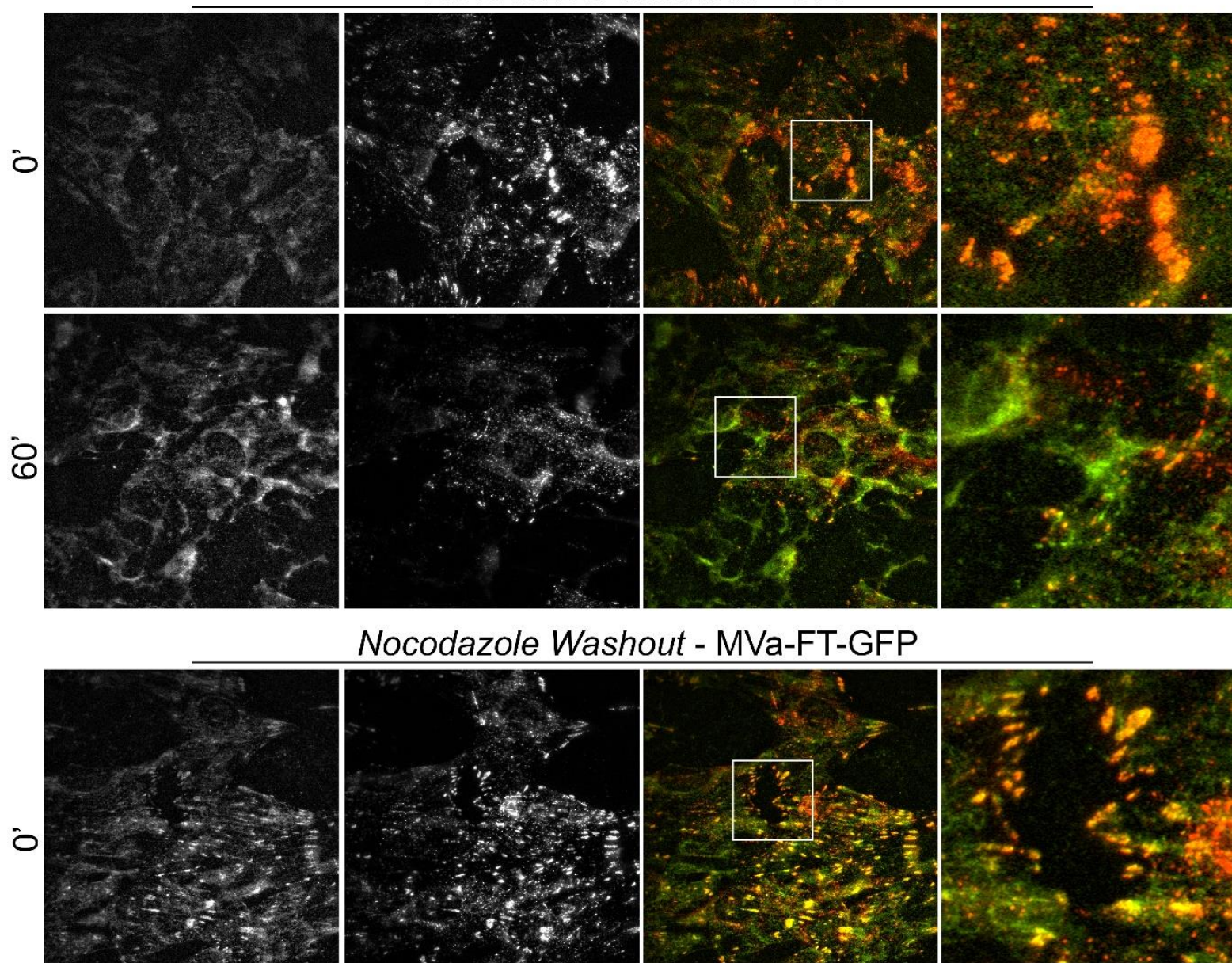

Nocodazole Washout - MVa-FT-GFP

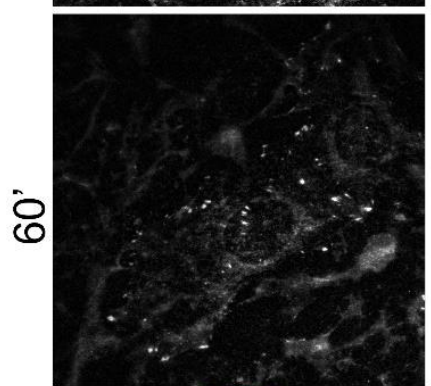

GFP
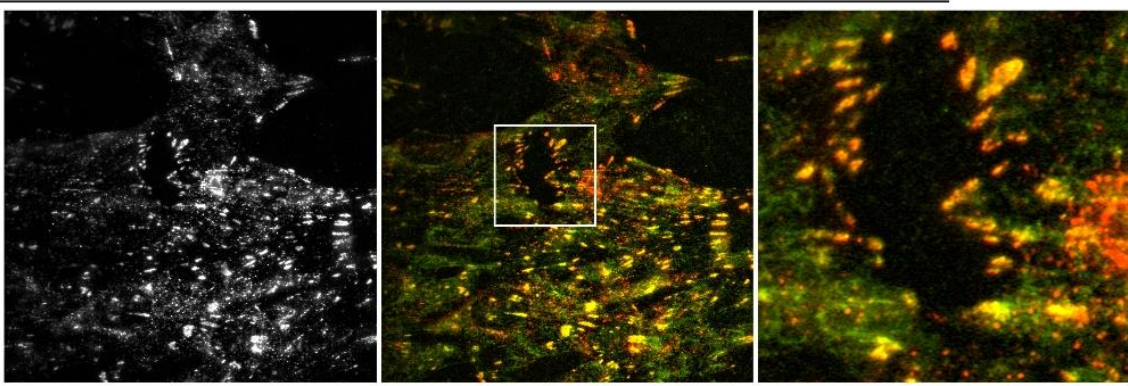

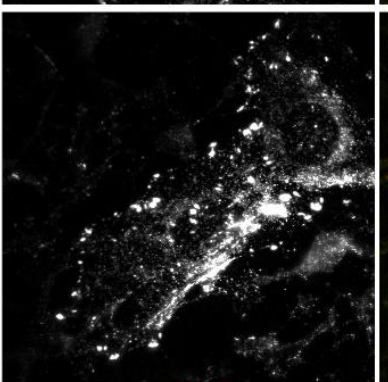

pFAK

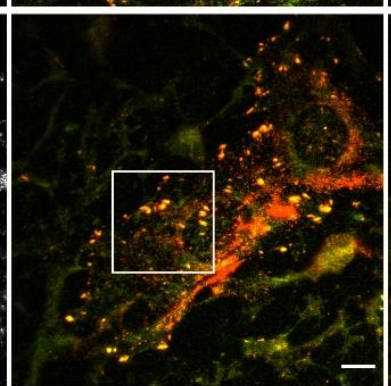

Merge

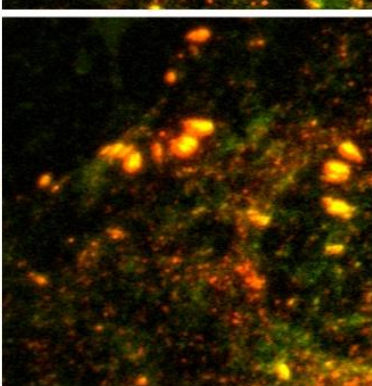

Zoom

Figura 14: A expressão de um dominante negativo da miosina-Va afeta a desmontagem das adesões focais. Microscopia TIRF de celulas NIH 3T3 expressando apenas GFP (cima) ou MVa-FT-GFP (baixo). Células tratadas com nocodazol por $4 \mathrm{~h}$, onde 60 minutos após a lavagem do nocodazol as AFs se desmontam normalmente nas células expressando GFP. Nas células expressando MVa-FT-GFP (dominante negativo da MVa) não há uma desmontagem completa das AFs após a lavagem do nocodazol. (GFP em verde, pFAK em vermelho). $n=2$ experimentos independentes. Barra de escala $10 \mu \mathrm{m}$. 


\subsection{A FAK não afeta o recrutamento da miosina-Va para as adesões focais}

Nader G., mostrou em sua dissertação de mestrado que há uma interação física entre a miosina-Va e a FAK, e para testar se há uma influência da FAK no recrutamento da miosinaVa para as adesões focais utilizamos as células nulas para FAK (FAK -/-) e células reexpressando a FAK (DP3). As células nulas para FAK não conseguem desmontar suas AFs como já demonstrado por Ezratty et al., 2009, mas mesmo na ausência da FAK a MVa se localiza nas AFs, tanto no tempo 0' quanto 60 minutos após a lavagem do nocodazol (Figura 15, cima). Já nas células reexpressando a FAK as células voltam a desmontar suas AFs normalmente e a MVa se localiza nas AFs (Figura 15, baixo).

Após a lavagem do nocodazol é possível reparar uma diferença na marcação da MVa entre as células FAK-/- e DP3, onde nas células nulas a marcação de MVa é mais forte e parece estar mais fortemente localizada próxima da membrana plasmática e das AFs, o que pode ser pelo fato de as células nulas serem menores e mais arredondadas que as DP3 ou porque a MVa está sendo constantemente recrutada para as AFs numa tentativa da célula de desmontar suas adesões. Esse resultado mostra que a falta da FAK não diminui o recrutamento da MVa para as AFs. 
Nocodazole Washout - FAK-/-
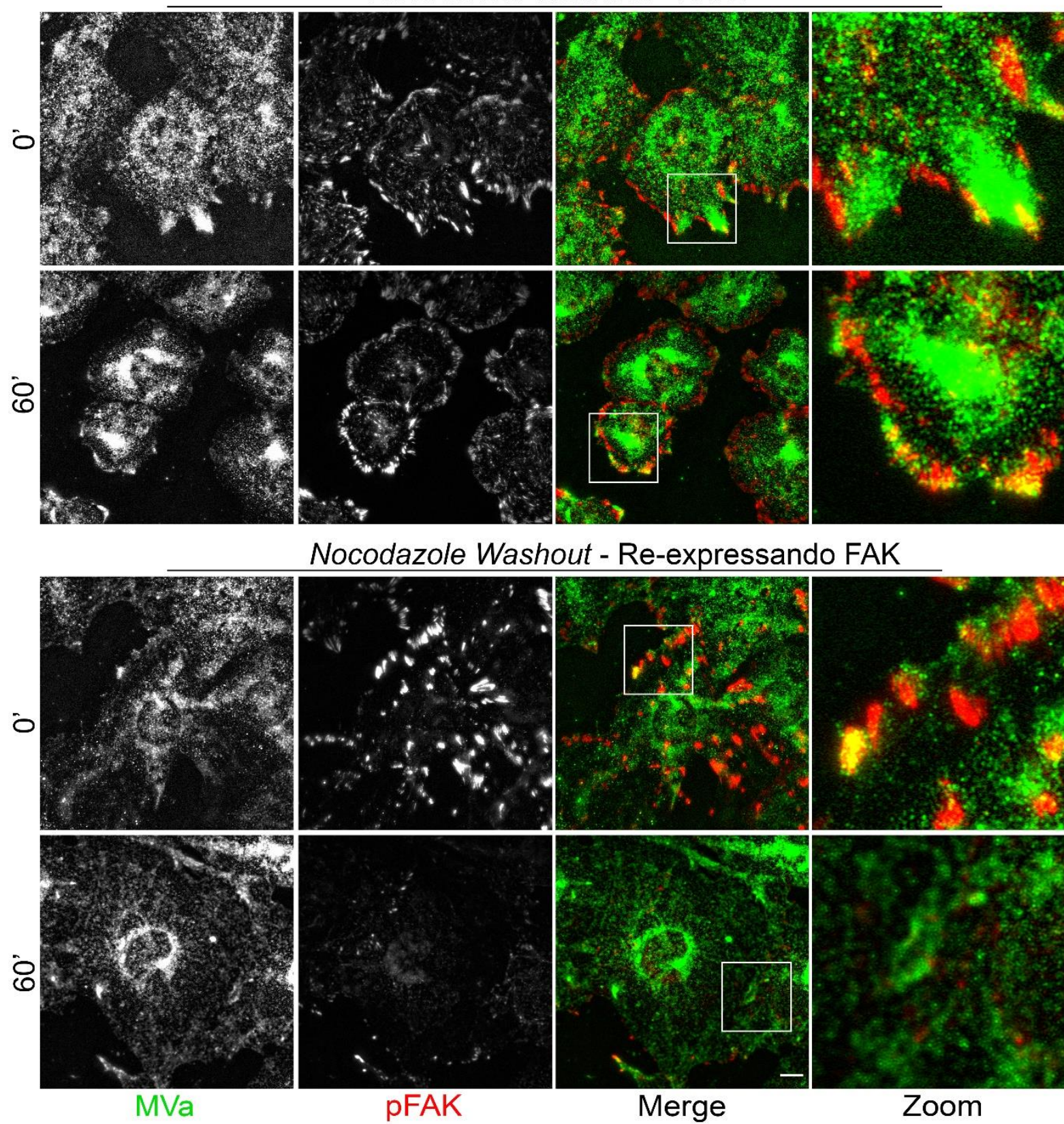

Figura 15: A ausência da FAK não afeta o recrutamento da miosina-Va para as adesões focais. Microscopia TIRF após tratamento por nocodazol em células nulas para FAK (FAK-/-) e reexpressando FAK (DP3). Nas células nulas não há desmontagem das AFs e há uma localização da miosina-Va nas AFs (cima). Nas células reexpressando a FAK a desmontagem das AFs acontece de forma normal (baixo), e há colocalização aparentemente menor da MVa com as AFs em comparação com as células nulas. As células foram marcadas para MVa (anti-cabeça; em verde) e pFAK (vermelho). $\mathrm{n}=2$ experimentos independentes. Barra de escala $10 \mu \mathrm{m}$. 


\subsection{A miosina-Va é importante para o recrutamento de Clatrina e Dinamina-2 para as}

\section{Adesões Focais}

Para entender como a MVa participa da desmontagem das adesões focais fomos analisar o recrutamento de proteínas que participam da desmontagem das AFs, como a dinamina-2 e a clatrina. Após alguns testes percebemos que o melhor tempo para se analisar isto, é 20 minutos após a lavagem, onde há uma maior presença dessas proteínas nas AFs. Após o tratamento com nocodazol comparamos a localização da clatrina e da dinamina-2 nas adesões focais em células controle e silenciadas para MVa.

Após 4h de tratamento com nocodazol há uma forte localização da clatrina na região das AFs tanto nas células controle quanto nas silenciadas, e a clatrina se localiza nas AFs que ainda não desmontaram, mesmo após 20 minutos da lavagem, em contraste com as células silenciadas onde há uma menor presença da clatrina nas AFs que ainda permanecem na célula (Figura 16A e 16C). A quantificação da clatrina na região das AFs foi feita através da região selecionada pelo canal da vinculina, e a intensidade de fluorescência foi medida no canal da clatrina (Figura 16B).

Já a presença da dinamina-2 nas AFs em células controle, após 20 minutos da lavagem do nocodazol, aumenta ainda mais quando comparada ao tempo 0' (4h de tratamento com nocodazol). E embora a quantidade de dinamina-2 nas AFs das células controle e silenciadas $4 \mathrm{~h}$ após o tratamento com nocodazol seja parecida, diferente das células controle onde ocorre um aumento da dinamina-2 nas AFs que ainda não desmontaram, a presença da dinamina-2 nas AFs, que ainda não desmontaram, das células silenciadas para MVa reduz (Figura 16D e 16E).

Juntos esses dados sugerem que a MVa participa da desmontagem das AFs através do recrutamento de proteínas essenciais para a desmontagem como dinamina-2 e clatrina, uma vez que as AFs remanescentes nas células silenciadas para MVa, 20 minutos após a lavagem, possuem uma quantidade menor de clatrina e dinamina-2. 


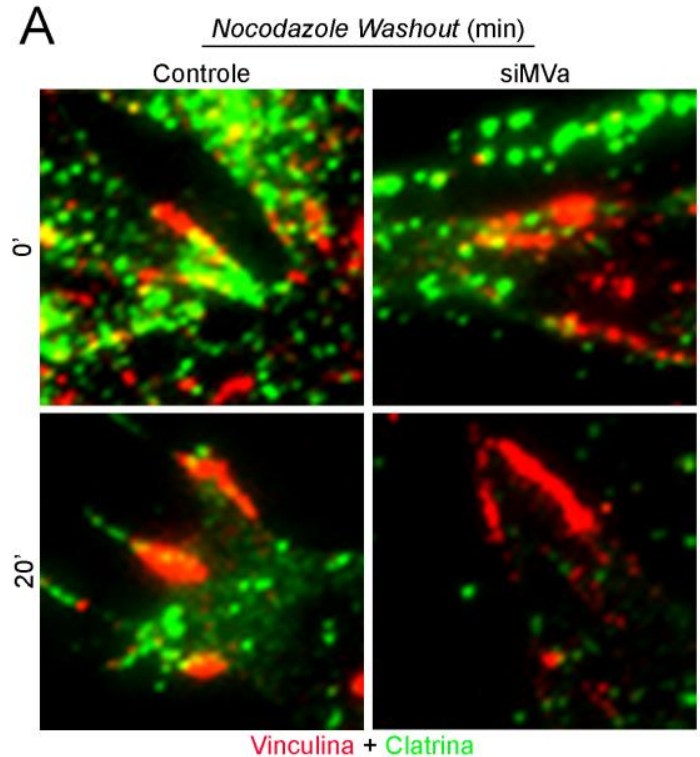

Docodazole Washout (min)

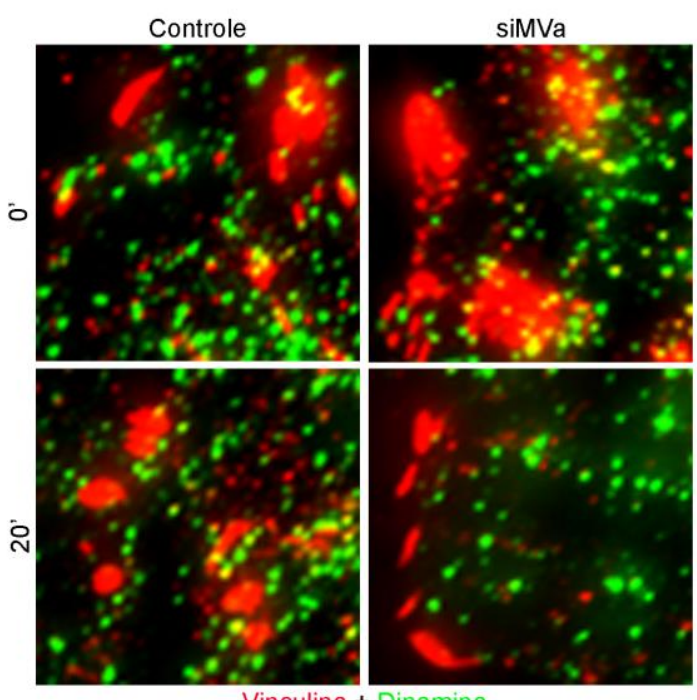

B

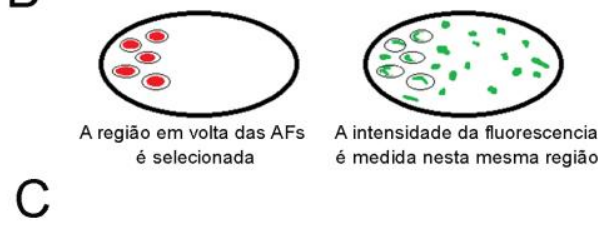

Clatrina nas AFs

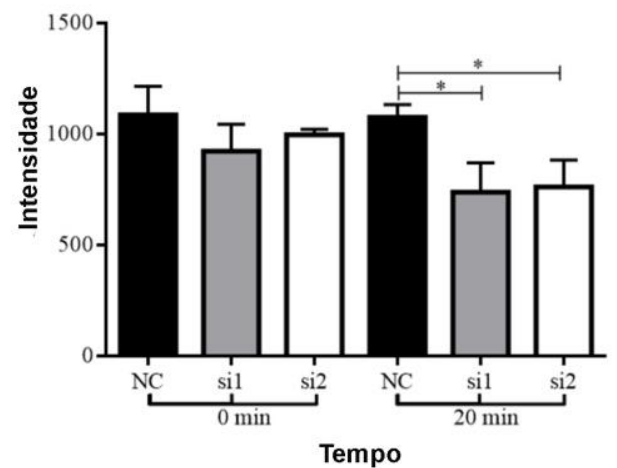

$E$

Dinamina nas AFs

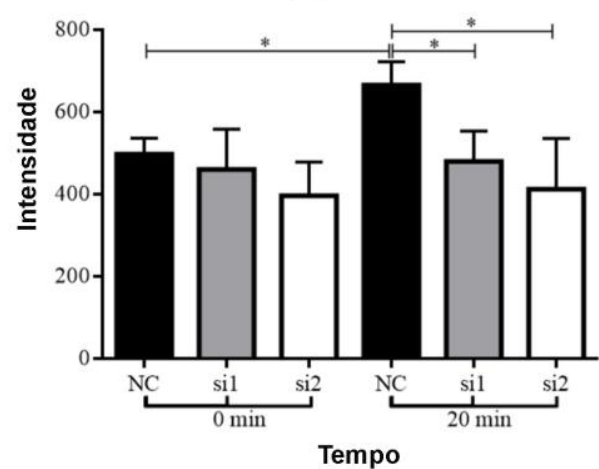

Figura 16: Miosina-Va é importante para o recrutamento de Clatrina e Dinamina-2 para as adesões focais.

A) Microscopia TIRF de celulas NIH 3T3 controle e silenciadas para MVa marcadas para vinculina (vermelho) e clatrina (verde), as celulas foram privadas de soro por $48 \mathrm{~h}$, tratadas com nocodazol por $4 \mathrm{~h}$, fixadas e analisadas no tempo 0 e 20 minutos após a lavagem do nocodazol. B) Desenho esquematico de como foi feita a quatificação das proteinas na região das AFs, foram desenhados circulos em volta das AFs pelo canal da vinculina, e a quantificação do mesmo local foi feita no canal da clatrina e da dinamina. C) Quantificação da intensidade de fluorescencia de clatrina nas adesoes focais após tratamento com nocodazol. (NC-Si1 p=0.0462; NC-Si2 p=0.0459). D) Microscopia TIRF de celulas NIH 3T3 controle e silenciadas para MVa, marcadas para vinculina (vermelho) e dinamina-2 (verde), as celulas foram privadas de soro por $48 \mathrm{~h}$, tratadas com nocodazol por $4 \mathrm{~h}$, fixadas e analisadas no tempo 0 e 20 minutos após a lavagem do nocodazol. E) Quantificação da intensidade de fluorescencia de dinamina- 2 nas adesoes focais após tratamento com nocodazol. (NC-NC p=0.0133; NC-Si1 p=0.0261; NC-Si2 p= 0.0318). $\mathrm{n}=$ foram quantificadas pelo menos 200 adesões focais por experimento em 3 experimentos independentes. 


\section{Discussão}

A montagem e desmontagem de adesões focais (AFs) é crucial para a migração celular, e uma melhor compreensão de como esses processos ocorrem é fundamental para entender o funcionamento das células, como e quando elas migram e o processo de invasão no câncer. Dados prévios do nosso grupo trazem uma forte correlação entre MVa, AFs e migração celular, em sua dissertação de mestrado, Nader 2010, mostrou que a MVa interage fisicamente com a FAK e que a MVa posiciona a FAK nos filopódios. Em sua tese de doutorado, Ramão 2016, mostrou que a MVa é requerida para a desmontagem das AFs, e que o silenciamento da MVa afeta a taxa de adesão das células e a velocidade de migração celular. Durante meu mestrado analisamos a distribuição e marcação da MVa em células estimuladas por soro. Mostramos que o soro provoca aumento da marcação de MVa fosforilada, mas que não afeta a quantidade total de miosina-Va, portanto, inferimos que esse aumento seja por ativação de quinases que tem o resíduo de S1650 como alvo de fosforilação.

A MVa tem um papel na invasão e migração celular (ALVES et al., 2013; LAN et al., 2010), procuramos entender aqui como miosina-Va afeta a migração celular, processo tão importante para as células. O presente trabalho traz evidências que corroboram a participação da miosina-Va na dinâmica das AFs. Analisamos componentes isolados do soro para identificar qual é o componente que induz essa fosforilação, buscando primeiramente responder se o aumento na fosforilação coincide especificamente com um estímulo apropriado para formação de AFs e fibras de estresse, ou seja, o ácido lisofosfatídico (LPA)? Assim como no estímulo por soro, o estímulo por LPA, também induz o aumento na marcação de miosina- $\mathrm{V}$ fosforilada e a localização da miosina- $\mathrm{V}$ fosforilada nas AFs. $\mathrm{O}$ componente do soro que induz a montagem das AFs a formação de fibras de estresse em células quiescentes e vias de Rho, que induzem a maturação das AFs é o LPA (RIDLEY; HALL, 1992). O LPA também induz as vias intracelulares proliferação, adesão e migração celular, (SHENG et al., 2015). Considerando que o LPA induz aumento do cálcio intracelular (LAPIERRE et al., 2010; XU et al., 2008), e que o cálcio regula a atividade ATPásica (NASCIMENTO et al., 1996; TAUHATA et al., 2001) e motora da MVa (CHENEY et al., 1993; LU et al., 2012), essa ativação da MVa por LPA, levanta a hipótese de que a fosforilação da MVa, nesse caso, possa ser pela CaMKII, quinase dependente de cálcio e descrita por fosforilar a MVa e (COELHO; LARSON, 1993; COSTA et al., 1999; KARCHER et al., 2001). 
Analisamos também se outros componentes do soro, como EGF e Insulina afetam a distribuição e fosforilação da miosina-V. Nossos resultados mostram um aumento na marcação da miosina-V fosforilada após estímulos por EGF, Insulina e LPA. Assim, concluímos que a ativação da fosforilação não é um evento especificamente associado à formação de adesões focais. De certa maneira isso já era esperado, uma vez que trabalhos prévios em células adiposas e musculares já mostravam que a miosina-Va é alvo de fosforilação da quinase Akt2, no mesmo resíduo de aminoácido mapeado como alvo da CaMKII, de maneira estimulada por insulina (YOSHIZAKI et al., 2007). No caso de EGF, sabemos que EGF induz a ativação de Rac1 e Cdc42 (KUROKAWA et al., 2004), e que Rac1 e Cdc42 induzem a formação do lamelipódio e de filopódios (NOBES; HALL, 1995), e considerando que a MVa está associada com a formação dessas estruturas (TSAKRAKLIDES et al., 1999) é provável que a ativação da MVa por EGF faça parte da via de formação ou dinâmica do lamelipódio e de filopódios.

A queda na marcação de miosina-V fosforilada após 30 min do estímulo por soro, LPA, insulina e EGF é mais um indício de que o aumento da marcação da miosina-V fosforilada reflita um aumento na taxa de fosforilação, devido a ativação de quinases especificas, e não aumento da síntese proteica, tendo em vista que as vias de sinalização são altamente controladas pela célula e após os estímulos induzirem a ativação de quinases, fosfatases entram em ação para manter um equilíbrio na célula (NEWMAN; ZHANG; ZHU, 2014). Os níveis de miosinaV fosforilada após 30 minutos do estímulo voltam a ser os mesmos do tempo 0', ou seja, antes do estímulo acontecer.

Outro ponto interessante é a redistribuição da miosina-V fosforilada após os estímulos. Já foi demonstrado que a MVa pode ser ativada por cálcio na região do retículo endoplasmático o que dá início ao transporte de vesículas pela MVa do retículo até a membrana plasmática (WADA et al., 2016). Quando a MVa está em uma conformação fechada, ela está em sua forma inativa, essa conformação ocorre quando o domínio da cauda globular da MVa se liga diretamente a região da cabeça, e altos níveis de cálcio ou a interação com o cargo reduzem essa interação, ativando a atividade motora da MVa (ARMSTRONG et al., 2012; YAO et al., 2015). A redistribuição da MVa que observamos após o estímulo, pode ser devido a sua atividade motora, atividade regulada e ativada pelos maiores níveis de cálcio intracelular após os estímulos no caso do LPA, e pela ativação de Akt2 nos estímulos por EGF e Insulina. Também EGF e insulina podem levar a ativação de fosfolipases c, que agiriam na hidrólise de fosfatidilinositídeos formando IP3, que tem um papel direto na liberação de cálcio do retículo endoplasmático (PUTNEY; TOMITA, 2012; SCHÖFL et al., 1999; WANG; WANG, 2003). 
Essa redistribuição da miosina-Va já foi descrita no caso do estímulo por insulina, onde a MVa se redistribui da região perinuclear da célula para a membrana plasmática, e foi demonstrado que essa redistribuição se dá devido ao papel da MVa, a qual leva GLUT4 até a membrana plasmática (YOSHIZAKI et al., 2007).

Uma vez que o anticorpo para miosina-V fosforilada reconhece MVa, MVb e MVc, não podemos descartar que esses estímulos também induzem a fosforilação das MVb e MVc, mas sabendo que a MVb participa do transporte de organelas dependente de actina (TRYBUS, 2008), da regulação da homeostase da membrana plasmática (SONAL et al., 2014) e tem um papel de supressor tumoral, onde sua expressão é perdida durante a progressão do câncer de colon (LETELLIER et al., 2017). A MVc está envolvida na exocitose de grânulos secretórios e aparece em compartimentos intracelulares distintos da MVa (JACOBS et al., 2009). Já a MVa, dá suporte a funções de crescimento, migração e adesão celular (TRYBUS, 2008), e já foi demonstrado a participação da MVa na via de insulina (YOSHIZAKI et al., 2007), a principal candidata de uma participação na via de LPA é a MVa. A MVa também está envolvida na via de EGF, onde EGF induz o recrutamento de KCC4, proteína que participa da reorganização do citoesqueleto de actina via associação com ezrina, do citoplasma até a membrana plasmática através da MVa (CHEN et al., 2009),

O processo de montagem das AFs já é bem caracterizado e diversos de seus componentes já estão descritos (DE PASCALIS; ETIENNE-MANNEVILLE, 2017), e nos perguntamos se a MVa seria necessária para a formação das adesões focais, devido a sua presença nas AFs após estímulo por LPA, e pelo fato de o LPA induzir a formação de fibras de estresse, formação das AFs e aumento na fosforilação da miosina-V. Mas como observamos, mesmo após o silenciamento da MVa, as AFs se formam normalmente após o estímulo por soro, o que nos levou então a analisar uma possível participação da MVa na desmontagem das AFs. Para entender melhor este papel da MVa na migração, resolvemos utilizar os experimentos que possibilitam estudar a montagem e a desmontagem das AFs. Esses estudos foram impulsionados inicialmente pela evidência da associação da MVa com FAK, tendo em vista que FAK é uma quinase requerida para desmontagem das AFs (HAMADI; et al., 2005).

Passamos então a analisar a desmontagem das AFs e se a MVa poderia estar envolvida neste importante passo da migração celular, para isto, utilizamos o tratamento com nocodazol, experimento bem descrito na literatura, o qual despolimeriza os microtúbulos das células, bloqueando a desmontagem das AFs, uma vez que os microtúbulos são importantes para a este 
processo (EZRATTY et al., 2009). Durante a desmontagem das AFs, a autofosforilação de FAK recruta dinamina-2 para as AFs, a qual chega até as AFs através dos microtúbulos (EZRATTY et al, 2009; WANG et al., 2011).

Com o silenciamento da MVa mostramos que a célula perde a habilidade de desmontar completamente as AFs após a lavagem do nocodazol, onde pelo menos $40 \%$ das AFs permanecem mesmo 60 minutos após a lavagem. Importante ressaltar aqui que o silenciamento da MVa não interfere nos níveis de MVb e MVc, os quais são marcados pelo anticorpo para miosina-V fosforilada. Interessante notar também, que a redistribuição celular da MVa 100 minutos após a lavagem com nocodazol, nas imagens de SIM (Figura 10), a MVa parece estar se redistribuindo em um padrão semelhante aos estímulos por soro. Embora esse padrão não seja perceptível nas imagens de microscopia confocal ou TIRF, isto pode indicar que a MVa esteja participando da reciclagem das AFs. Entretanto, não conseguimos explorar essa hipótese, e uma maneira de avaliar essa participação seria micro injetar a cauda inteira da MVa 60 minutos após a lavagem do nocodazol, onde as AFs já estariam desmontadas. A micro-injeção da proteína dominante negativa diretamente no citoplasma das células daria uma resposta imediata, e com as AFs já desmontadas, seria possível analisar se há um defeito no turnover das AFs, uma vez que como as AFs não desmontam completamente nas células silenciadas, não podemos afirmar se o defeito na remontagem das AFs é devido ao defeito na desmontagem ou se a MVa estaria também participando da remontagem.

A vídeo microscopia mostra mais detalhadamente como se dá o defeito na desmontagem das AFs, onde fica possível perceber uma diminuição da intensidade de fluorescência e um menor tamanho das AFs. Isso pode ser por uma pequena perda do sinal de GFP, devido a exposição ao laser do microscópio, ou que algumas proteínas ou até uma porção das AFs são endocitadas, mas não a AF inteira. As AFs que não se desmontaram até 20-30 minutos permanecem na célula mesmo 120 minutos após a lavagem do nocodazol. Durante o processo de desmontagem das AFs, a Src fosforila a dinamina-2, induzindo a endocitose das AFs (WANG et al., 2011) e células nulas para FAK ou expressando dominante negativo de dinamina-2 também tem problemas na desmontagem (EZRATTY et al., 2009), então levantamos a hipótese de que a MVa poderia estar interagindo, modificando a associação delas com as AFs ou levando essas proteínas até as AFs. A FAK, Talina e PIPKI $\gamma$ regulam a ativação das integrinas endocitadas de modo a polarizar a montagem das AFs (NADER; EZRATTY; GUNDERSEN, 2016), a fosforilação da FAK no resíduo Y397 é muito importante desmontagem, e a FAK é uma proteína constituinte das adesões e participa das vias de 
internalização de sinas extracelulares e do recrutamento de dinamina-2 para as AFs (DE PASCALIS; ETIENNE-MANNEVILLE, 2017). Decidimos então, analisar se o silenciamento da MVa afeta a localização da FAK nas AFs, e nossos dados sugerem que a MVa não interfere na localização subcelular da FAK e nem na fosforilação no resíduo Y397, uma vez que a marcação de pFAK (FAK-Y397) é semelhante nas células controle e silenciadas para MVa. Somado a isso, o recrutamento da MVa para as AFs não é afetado pela ausência da FAK, onde em células nulas para FAK, a MVa ainda se localiza nas AFS, embora nossos resultados demonstram que as células nulas para FAK tenham um fenótipo mais forte do que o obtido com o silenciamento da MVa, em relação a desmontagem das AFs, isso pode ser devido a FAK ter um papel mais decisivo ou mais geral do que a MVa na desmontagem das AFs ou pelo fato de que o silenciamento da MVa não ser completo. De fato, a eficiência do silenciamento da miosina-Va foi apenas da ordem de 40 a 60\%, invalidando a comparação com células nulas, onde não há expressão alguma da FAK.

A desmontagem e endocitose das integrinas das AFs pode ocorrer via clatrina, onde a clatrina é recrutada para as AFs após o recrutamento de dinamina (CHAO; KUNZ, 2009). Com uma participação importante da clatrina no processo de desmontagem, nos perguntamos se o recrutamento de clatrina para as adesões focais acontece de forma normal nas células silenciadas para MVa. E demonstramos aqui que esse recrutamento parece ser defeituoso, onde as AFs remanescentes, após 20 minutos da lavagem do nocodazol, têm uma presença menor de clatrina na região próxima da AF. Outra proteína importante para a desmontagem é a dinamina2, que também é requerida para a desmontagem das AFs e além auxiliar no recrutamento da clatrina, participa diretamente da endocitose das integrinas, auxiliando na invaginação da membrana plasmática durante o processo de endocitose (NAGANO et al., 2012). Ao avaliarmos a localização e recrutamento da dinamina-2 para as AFs após tratamento com nocodazol, percebemos que assim como a clatrina, a dinamina- 2 também é menos recrutada e está menos presente nas AFs de células silenciadas para MVa, sugerindo que a MVa participa do recrutamento de ambas as proteínas para as adesões focais. Sem a presença de dinamina-2 as AFs não são desmontadas (EZRATTY et al., 2009), e com um papel no recrutamento dessa proteína, a MVa teria, de fato, um papel central na desmontagem das AFs. Essa conclusão é compatível com as observações descritas por Ramão, 2014 e com os dados complementares obtidos no presente trabalho.

Dessa maneira, levanta-se 2 hipóteses (Figura 17), a primeira que a MVa interage fisicamente com essas proteínas; a segunda, que a MVa participa do targeting dos microtúbulos 
nas AFs. Um dos pontos para resolver nessa questão seria realizar a imunoprecipitação da MVa para verificar uma interação da MVa com as proteínas da AF. A segunda hipótese, de que a MVa participa do targeting dos microtúbulos nas AFs, baseia-se na observação de que a desmontagem das AFs se dá logo após o targeting dos microtúbulos nas AFs (EZRATTY; PARTRIDGE; GUNDERSEN, 2005) e a MVa já foi descrita como interagindo diretamente e indiretamente com proteínas da ponta 'mais' dos microtúbulos em crescimento (WU; TSAN; HAMMER, 2005). Além disso, a miosina-Va também serve de ancora para carreadores moleculares associados a microtúbulos como a kinesina, permitindo que a kinesina viaje sobre os microtúbulos por uma distância maior quando associada a MVa (ALI et al., 2008). A proteína Eb1 é um componente da ponta mais dos microtúbulos em crescimento e participa do targeting dos microtúbulos. Já foi demonstrado que Eb1 e MVa participam da entrega de melanofilina aos melanossomos. Da mesma maneira, a MVa poderia estar participando juntamente com Eb1 do targeting dos microtúbulos nas AFs, e a diminuição de clatrina e dinamina-2 nas AFs após tratamento com nocodazol das células silenciadas para MVa pode ser devido a um defeito no targeting dos microtúbulos, o qual pode estar sendo menos especifico para as AFs ou requer a MVa para a correta ancoragem dos microtúbulos sobre as AFs, uma vez que a MVa já foi demonstrada fazer esse crosslink entre actina e microtúbulos (WU; TSAN; HAMMER, 2005).

Mostramos aqui que o LPA induz não apenas a montagem das AFs, como já descrito por Ridley e Hall, 1992, mas também induz a fosforilação da miosina-Va. Entretanto, nossos dados mostram que a MVa não é necessária para a montagem das AFs, uma vez que seu silenciamento não interfere neste processo. Desta maneira, não detectamos diferenças claras na montagem das AFs após estímulo por soro ou tratamento com nocodazol nas células silenciadas para MVa, sendo que a presença da MVa nas adesões focais após estímulo por soro ou tratamento com nocodazol sugere um papel da MVa na dinâmica das AFs. Nosso trabalho coloca a miosina-Va como um importante componente da dinâmica das adesões focais, onde a MVa participa de forma decisiva do recrutamento de proteínas como clatrina e dinamina-2 e da desmontagem das AFs. Ainda precisa ser melhor investigado como a MVa exerce esse papel na célula, e analisar o targeting dos microtúbulos através de vídeo microscopia TIRF de células silenciadas para a MVa pode responder essa pergunta, demonstrando se há de fato algum problema no targeting, onde podem ser analisados o tempo que os microtúbulos levam para chegar e se ficam associados as AFs após tratamento por nocodazol. 

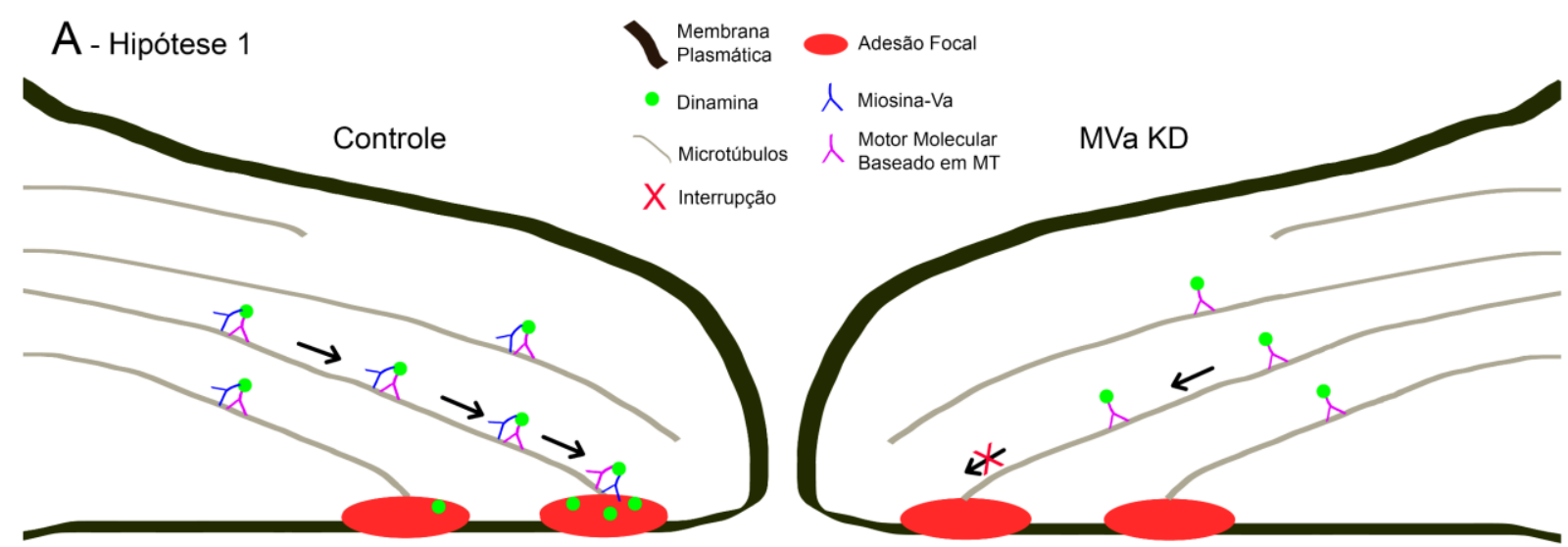

B - Hipótese 2
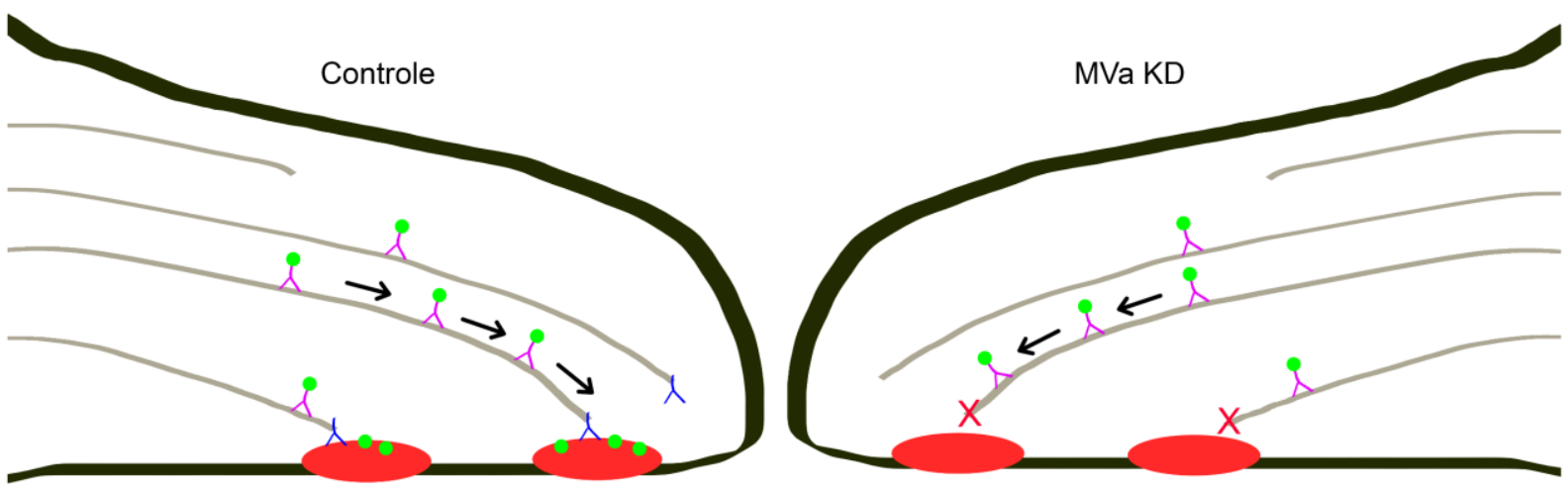

Figura 17: Hipóteses sobre a participação da MVa na desmontagem das adesões focais. A) Hipótese 1, a MVa serve como âncora para o motor molecuar que leva a dinamina até as adesões focais, e na ausência de MVa (MVa KD), a dinamina não chega até as AFs, impossibilitando a desmontagem. B) Hipótese 2, a MVa participa do targeting dos microtíbulos, e direciona os microtúbulos para as adesões focais, na ausência de MVa (MVa KD), os microtúbulos não chegam até as AFs, impossibilitando a desmontagem. 


\section{Conclusões}

-EGF, Insulina e LPA induzem a fosforilação da MVa, mas apenas o LPA induz a formação das adesões focais.

- O silenciamento da miosina-Va não afeta a montagem das adesões focais após estímulo por soro ou tratamento com nocodazol.

- Há uma colocalização de miosina-V fosforilada e de FAK fosforilada nas adesões focais após estímulo por LPA e tratamento com nocodazol.

- Tanto o silenciamento da miosina-Va quanto a expressão do dominante negativo de miosina-Va (cauda inteira) interferem na desmontagem das adesões focais, demonstrando que a miosina-Va é importante para a endocitose das adesões e para a migração celular.

- Células nulas para FAK não desmontam suas adesões focais após tratamento com nocodazol e a FAK parece não ser necessária para o recrutamento de miosina-Va para as adesões focais.

- A miosina-Va afeta o recrutamento de dinamina-2 e de clatrina para as adesões focais. 


\section{Referências}

ALAHARI, S. K.; REDDIG, P. J.; JULIANO, R. L. Biological aspects of signal transduction by cell adhesion receptors. Int Rev Cytol, 220, p. 145-184, 2002.

ALI, M. Y.; LU, H.; BOOKWALTER, C. S.; WARSHAW, D. M. et al. Myosin V and Kinesin act as tethers to enhance each others' processivity. Proc Natl Acad Sci U S A, 105, n. 12, p. 4691-4696, Mar 2008.

ALVES, C. P.; MORAES, M. H.; SOUSA, J. F.; PONTES, C. L. S. et al. Myosin-Va contributes to manifestation of malignant-related properties in melanoma cells. J Invest Dermatol, 133, n. 12, p. 2809-2812, Dec 2013.

ANDERSON, L. R.; OWENS, T. W.; NAYLOR, M. J. Integrins in development and cancer. Biophys Rev, 6, n. 2, p. 191-202, Jun 2014.

ARMSTRONG, J. M.; KREMENTSOVA, E.; MICHALEK, A. J.; HEASLIP, A. T. et al. Full-length myosin Va exhibits altered gating during processive movement on actin. Proc Natl Acad Sci U S A, 109, n. 5, p. E218-224, Jan 2012.

BAINES, A. J.; LU, H. C.; BENNETT, P. M. The Protein 4.1 family: hub proteins in animals for organizing membrane proteins. Biochim Biophys Acta, 1838, n. 2, p. 605-619, Feb 2014.

BOVELLAN, M.; FRITZSCHE, M.; STEVENS, C.; CHARRAS, G. Death-associated protein kinase (DAPK) and signal transduction: blebbing in programmed cell death. FEBS J, 277, n. 1, p. 58-65, Jan 2010.

CALDERWOOD, D. A.; CAMPBELL, I. D.; CRITCHLEY, D. R. Talins and kindlins: partners in integrinmediated adhesion. Nat Rev Mol Cell Biol, 14, n. 8, p. 503-517, Aug 2013.

CASE, L. B.; BAIRD, M. A.; SHTENGEL, G.; CAMPBELL, S. L. et al. Molecular mechanism of vinculin activation and nanoscale spatial organization in focal adhesions. Nat Cell Biol, 17, n. 7, p. 880-892, Jul 2015.

CASE, L. B.; WATERMAN, C. M. Integration of actin dynamics and cell adhesion by a three-dimensional, mechanosensitive molecular clutch. Nat Cell Biol, 17, n. 8, p. 955-963, Aug 2015.

CASWELL, P. T.; NORMAN, J. C. Integrin trafficking and the control of cell migration. Traffic, 7, n. 1, p. 14-21, Jan 2006.

CASWELL, P. T.; VADREVU, S.; NORMAN, J. C. Integrins: masters and slaves of endocytic transport. Nat Rev Mol Cell Biol, 10, n. 12, p. 843-853, Dec 2009. 
CHAO, W. T.; KUNZ, J. Focal adhesion disassembly requires clathrin-dependent endocytosis of integrins. FEBS Lett, 583, n. 8, p. 1337-1343, Apr 2009.

CHARRAS, G.; PALUCH, E. Blebs lead the way: how to migrate without lamellipodia. Nat Rev Mol Cell Biol, 9, n. 9, p. 730-736, Sep 2008.

CHEN, Y. F.; CHOU, C. Y.; WILKINS, R. J.; ELLORY, J. C. et al. Motor protein-dependent membrane trafficking of $\mathrm{KCl}$ cotransporter-4 is important for cancer cell invasion. Cancer Res, 69, n. 22, p. 85858593, Nov 2009.

CHENEY, R. E.; O'SHEA, M. K.; HEUSER, J. E.; COELHO, M. V. et al. Brain myosin-V is a two-headed unconventional myosin with motor activity. Cell, 75, n. 1, p. 13-23, Oct 1993.

COELHO, M. V.; LARSON, R. E. Ca(2+)-dependent phosphorylation of the tail domain of myosin-V, a calmodulin-binding myosin in vertebrate brain. Braz J Med Biol Res, 26, n. 5, p. 465-472, May 1993.

COSTA, M. C.; MANI, F.; SANTORO, W.; ESPREAFICO, E. M. et al. Brain myosin-V, a calmodulin-carrying myosin, binds to calmodulin-dependent protein kinase II and activates its kinase activity. J Biol Chem, 274, n. 22, p. 15811-15819, May 1999.

DE PASCALIS, C.; ETIENNE-MANNEVILLE, S. Single and collective cell migration: the mechanics of adhesions. Mol Biol Cell, 28, n. 14, p. 1833-1846, Jul 2017.

DESGROSELLIER, J. S.; CHERESH, D. A. Integrins in cancer: biological implications and therapeutic opportunities. Nat Rev Cancer, 10, n. 1, p. 9-22, Jan 2010.

ESPREAFICO, E. M.; CHENEY, R. E.; MATTEOLI, M.; NASCIMENTO, A. A. et al. Primary structure and cellular localization of chicken brain myosin- $\mathrm{V}$ (p190), an unconventional myosin with calmodulin light chains. J Cell Biol, 119, n. 6, p. 1541-1557, Dec 1992.

ETIENNE-MANNEVILLE, S. Microtubules in cell migration. Annu Rev Cell Dev Biol, 29, p. 471-499, 2013.

EVANS, R. D.; ROBINSON, C.; BRIGGS, D. A.; TOOTH, D. J. et al. Myosin-Va and dynamic actin oppose microtubules to drive long-range organelle transport. Curr Biol, 24, n. 15, p. 1743-1750, Aug 2014.

EZRATTY, E. J.; BERTAUX, C.; MARCANTONIO, E. E.; GUNDERSEN, G. G. Clathrin mediates integrin endocytosis for focal adhesion disassembly in migrating cells. J Cell Biol, 187, n. 5, p. 733-747, Nov 2009.

EZRATTY, E. J.; PARTRIDGE, M. A.; GUNDERSEN, G. G. Microtubule-induced focal adhesion disassembly is mediated by dynamin and focal adhesion kinase. Nat Cell Biol, 7, n. 6, p. 581-590, Jun 2005. 
FERGUSON, S. M.; DE CAMILLI, P. Dynamin, a membrane-remodelling GTPase. Nat Rev Mol Cell Biol, 13, n. 2, p. 75-88, Jan 2012.

FERGUSON, S. M.; FERGUSON, S.; RAIMONDI, A.; PARADISE, S. et al. Coordinated actions of actin and BAR proteins upstream of dynamin at endocytic clathrin-coated pits. Dev Cell, 17, n. 6, p. 811-822, Dec 2009.

FISH, K. N. Total internal reflection fluorescence (TIRF) microscopy. Curr Protoc Cytom, Chapter 12, p. Unit12.18, Oct 2009.

FRAME, M. C.; PATEL, H.; SERRELS, B.; LIETHA, D. et al. The FERM domain: organizing the structure and function of FAK. Nat Rev Mol Cell Biol, 11, n. 11, p. 802-814, Nov 2010.

GUNDERSEN, G. G.; WORMAN, H. J. Nuclear positioning. Cell, 152, n. 6, p. 1376-1389, Mar 2013.

GUO, F.; DEBIDDA, M.; YANG, L.; WILLIAMS, D. A. et al. Genetic deletion of Rac1 GTPase reveals its critical role in actin stress fiber formation and focal adhesion complex assembly. J Biol Chem, 281, n. 27, p. 18652-18659, Jul 2006.

GUO, W.; GIANCOTTI, F. G. Integrin signalling during tumour progression. Nat Rev Mol Cell Biol, 5, n. 10, p. 816-826, Oct 2004.

HAMADI, A.; BOUALI, M.; DONTENWILL, M.; STOECKEL, H. et al. Regulation of focal adhesion dynamics and disassembly by phosphorylation of FAK at tyrosine 397. J Cell Sci, 118, n. Pt 19, p. 4415-4425, Oct 2005.

HARTMAN, M. A.; SPUDICH, J. A. The myosin superfamily at a glance. J Cell Sci, 125, n. Pt 7, p. 16271632, Apr 2012.

HERTER, J.; ZARBOCK, A. Integrin Regulation during Leukocyte Recruitment. J Immunol, 190, n. 9, p. 4451-4457, May 2013.

HOWARD, J. Molecular motors: structural adaptations to cellular functions. Nature, 389, n. 6651, p. 561-567, Oct 1997.

HU, X.; JING, C.; XU, X.; NAKAZAWA, N. et al. Cooperative Vinculin Binding to Talin Mapped by TimeResolved Super Resolution Microscopy. Nano Lett, 16, n. 7, p. 4062-4068, 072016.

INNOCENTI, M. New insights into the formation and the function of lamellipodia and ruffles in mesenchymal cell migration. Cell Adh Migr, 12, n. 5, p. 401-416, 2018. 
IZIDORO-TOLEDO, T. C.; BORGES, A. C.; ARAÚJO, D. D.; MAZZI, D. P. et al. A myosin-Va tail fragment sequesters dynein light chains leading to apoptosis in melanoma cells. Cell Death Dis, 4, p. e547, Mar 2013.

JACOBS, D. T.; WEIGERT, R.; GRODE, K. D.; DONALDSON, J. G. et al. Myosin Vc is a molecular motor that functions in secretory granule trafficking. Mol Biol Cell, 20, n. 21, p. 4471-4488, Nov 2009.

JACQUEMET, G.; HAMIDI, H.; IVASKA, J. Filopodia in cell adhesion, 3D migration and cancer cell invasion. Curr Opin Cell Biol, 36, p. 23-31, Oct 2015.

KANCHANAWONG, P.; SHTENGEL, G.; PASAPERA, A. M.; RAMKO, E. B. et al. Nanoscale architecture of integrin-based cell adhesions. Nature, 468, n. 7323, p. 580-584, Nov 2010.

KARCHER, R. L.; ROLAND, J. T.; ZAPPACOSTA, F.; HUDDLESTON, M. J. et al. Cell cycle regulation of myosin-V by calcium/calmodulin-dependent protein kinase II. Science, 293, n. 5533, p. 1317-1320, Aug 2001.

KECHAGIA, J. Z.; IVASKA, J.; ROCA-CUSACHS, P. Integrins as biomechanical sensors of the microenvironment. Nat Rev Mol Cell Biol, 20, n. 8, p. 457-473, Aug 2019.

KLAPHOLZ, B.; BROWN, N. H. Talin - the master of integrin adhesions. J Cell Sci, 130, n. 15, p. 24352446, Aug 2017.

KNOWLES, B. C.; ROLAND, J. T.; KRISHNAN, M.; TYSKA, M. J. et al. Myosin Vb uncoupling from RAB8A and RAB11A elicits microvillus inclusion disease. J Clin Invest, 124, n. 7, p. 2947-2962, Jul 2014.

KUO, J. C.; HAN, X.; HSIAO, C. T.; YATES, J. R. et al. Analysis of the myosin-II-responsive focal adhesion proteome reveals a role for $\beta$-Pix in negative regulation of focal adhesion maturation. Nat Cell Biol, 13 , n. 4, p. 383-393, Apr 2011.

KUROKAWA, K.; ITOH, R. E.; YOSHIZAKI, H.; NAKAMURA, Y. O. et al. Coactivation of Rac1 and Cdc42 at lamellipodia and membrane ruffles induced by epidermal growth factor. Mol Biol Cell, 15, n. 3, p. 10031010, Mar 2004.

LAI, F. P.; SZCZODRAK, M.; OELKERS, J. M.; LADWEIN, M. et al. Cortactin promotes migration and platelet-derived growth factor-induced actin reorganization by signaling to Rho-GTPases. Mol Biol Cell, 20, n. 14, p. 3209-3223, Jul 2009.

LAN, L.; HAN, H.; ZUO, H.; CHEN, Z. et al. Upregulation of myosin Va by Snail is involved in cancer cell migration and metastasis. Int J Cancer, 126, n. 1, p. 53-64, Jan 2010.

LANGFORD, G. M. Myosin-V, a versatile motor for short-range vesicle transport. Traffic, 3, n. 12, p. 859-865, Dec 2002. 
LAPIERRE, D. M.; TANABE, N.; PEREVERZEV, A.; SPENCER, M. et al. Lysophosphatidic acid signals through multiple receptors in osteoclasts to elevate cytosolic calcium concentration, evoke retraction, and promote cell survival. J Biol Chem, 285, n. 33, p. 25792-25801, Aug 2010.

LARSON, R. E. Myosin-V: a class of unconventional molecular motors. Braz J Med Biol Res, 29, n. 3, p. 309-318, Mar 1996.

LEE, M. Y.; SKOURA, A.; PARK, E. J.; LANDSKRONER-EIGER, S. et al. Dynamin 2 regulation of integrin endocytosis, but not VEGF signaling, is crucial for developmental angiogenesis. Development, 141, n. 7, p. 1465-1472, Apr 2014.

LETELLIER, E.; SCHMITZ, M.; GINOLHAC, A.; RODRIGUEZ, F. et al. Loss of Myosin Vb in colorectal cancer is a strong prognostic factor for disease recurrence. Br J Cancer, 117, n. 11, p. 1689-1701, Nov 2017.

LU, Z.; SHEN, M.; CAO, Y.; ZHANG, H. M. et al. Calmodulin bound to the first IQ motif is responsible for calcium-dependent regulation of myosin 5a. J Biol Chem, 287, n. 20, p. 16530-16540, May 2012.

MCCAFFREY, M. W.; LINDSAY, A. J. Roles for myosin Va in RNA transport and turnover. Biochem Soc Trans, 40, n. 6, p. 1416-1420, Dec 2012.

MERCER, J. A.; SEPERACK, P. K.; STROBEL, M. C.; COPELAND, N. G. et al. Novel myosin heavy chain encoded by murine dilute coat colour locus. Nature, 349, n. 6311, p. 709-713, Feb 1991.

MESCHEDE, I. P.; SANTOS, T. O.; IZIDORO-TOLEDO, T. C.; GURGEL-GIANETTI, J. et al. Griscelli syndrometype 2 in twin siblings: case report and update on RAB27A human mutations and gene structure. Braz J Med Biol Res, 41, n. 10, p. 839-848, Oct 2008.

MÉNASCHÉ, G.; HO, C. H.; SANAL, O.; FELDMANN, J. et al. Griscelli syndrome restricted to hypopigmentation results from a melanophilin defect (GS3) or a MYO5A F-exon deletion (GS1). J Clin Invest, 112, n. 3, p. 450-456, Aug 2003.

NADER, G. P.; EZRATTY, E. J.; GUNDERSEN, G. G. FAK, talin and PIPKIy regulate endocytosed integrin activation to polarize focal adhesion assembly. Nat Cell Biol, 18, n. 5, p. 491-503, 052016.

NADER, G.P.F.; RAMÃO, A.; MESCHEDE, I.P.; IZIDORO-TOLEDO, T.C.; FRANCHINI, K.G.; LARSON, R.E.; ESPREAFICO, E.M. Myosin-Va mediates the positioning of FAK to cortical protrusions and promotes cell spreading and motility. Manuscrito em preparação.

NAGANO, M.; HOSHINO, D.; KOSHIKAWA, N.; AKIZAWA, T. et al. Turnover of focal adhesions and cancer cell migration. Int J Cell Biol, 2012, p. 310616, 2012. 
NASCIMENTO, A. A.; CHENEY, R. E.; TAUHATA, S. B.; LARSON, R. E. et al. Enzymatic characterization and functional domain mapping of brain myosin-V. J Biol Chem, 271, n. 29, p. 17561-17569, Jul 1996.

NEWMAN, R. H.; ZHANG, J.; ZHU, H. Toward a systems-level view of dynamic phosphorylation networks. Front Genet, 5, p. 263, 2014.

NING, Y.; BURANDA, T.; HUDSON, L. G. Activated epidermal growth factor receptor induces integrin alpha2 internalization via caveolae/raft-dependent endocytic pathway. J Biol Chem, 282, n. 9, p. 63806387, Mar 2007.

NOBES, C. D.; HALL, A. Rho, rac and cdc42 GTPases: regulators of actin structures, cell adhesion and motility. Biochem Soc Trans, 23, n. 3, p. 456-459, Aug 1995.

ODA, K.; MATSUOKA, Y.; FUNAHASHI, A.; KITANO, H. A comprehensive pathway map of epidermal growth factor receptor signaling. Mol Syst Biol, 1, p. 2005.0010, 2005.

ONODERA, Y.; NAM, J. M.; SABE, H. Intracellular trafficking of integrins in cancer cells. Pharmacol Ther, 140, n. 1, p. 1-9, Oct 2013.

PARSONS, J. T. Focal adhesion kinase: the first ten years. J Cell Sci, 116, n. Pt 8, p. 1409-1416, Apr 2003.

POINCLOUX, R.; AL SAATI, T.; MARIDONNEAU-PARINI, I.; LE CABEC, V. The oncogenic activity of the Src family kinase Hck requires the cooperative action of the plasma membrane- and lysosome-associated isoforms. Eur J Cancer, 45, n. 3, p. 321-327, Feb 2009.

PRUTZMAN, K. C.; GAO, G.; KING, M. L.; IYER, V. V. et al. The focal adhesion targeting domain of focal adhesion kinase contains a hinge region that modulates tyrosine 926 phosphorylation. Structure, 12, n. 5, p. 881-891, May 2004.

PUTNEY, J. W.; TOMITA, T. Phospholipase C signaling and calcium influx. Adv Biol Regul, 52, n. 1, p. 152-164, Jan 2012.

RAMÃO A. Miosina-Va promove a desmontagem das adesões focais e a migração celular. Tese (Doutorado em Biologia Celular e Molecular) 2014. Universidade de São Paulo - SP, 2014.

RECK-PETERSON, S. L.; PROVANCE, D. W.; MOOSEKER, M. S.; MERCER, J. A. Class V myosins. Biochim Biophys Acta, 1496, n. 1, p. 36-51, Mar 2000.

RIDLEY, A. J. Life at the leading edge. Cell, 145, n. 7, p. 1012-1022, Jun 2011.

RIDLEY, A. J.; HALL, A. The small GTP-binding protein rho regulates the assembly of focal adhesions and actin stress fibers in response to growth factors. Cell, 70, n. 3, p. 389-399, Aug 1992. 
RIDLEY, A. J.; SCHWARTZ, M. A.; BURRIDGE, K.; FIRTEL, R. A. et al. Cell migration: integrating signals from front to back. Science, 302, n. 5651, p. 1704-1709, Dec 2003.

ROBERTS, M.; BARRY, S.; WOODS, A.; VAN DER SLUIJS, P. et al. PDGF-regulated rab4-dependent recycling of alphavbeta3 integrin from early endosomes is necessary for cell adhesion and spreading. Curr Biol, 11, n. 18, p. 1392-1402, Sep 2001.

RODRIGUEZ, O. C.; CHENEY, R. E. Human myosin-Vc is a novel class $V$ myosin expressed in epithelial cells. J Cell Sci, 115, n. Pt 5, p. 991-1004, Mar 2002.

SAKAMOTO, T.; YILDEZ, A.; SELVIN, P. R.; SELLERS, J. R. Step-size is determined by neck length in myosin V. Biochemistry, 44, n. 49, p. 16203-16210, Dec 2005.

SCHÖFL, C.; MADER, T.; KRÄMER, C.; WARING, M. et al. Ca2+/calmodulin inhibition and phospholipase C-linked Ca2+ Signaling in clonal beta-cells. Endocrinology, 140, n. 12, p. 5516-5523, Dec 1999.

SHENG, X.; YUNG, Y. C.; CHEN, A.; CHUN, J. Lysophosphatidic acid signalling in development. Development, 142, n. 8, p. 1390-1395, Apr 2015.

SHI, F.; SOTTILE, J. Caveolin-1-dependent beta1 integrin endocytosis is a critical regulator of fibronectin turnover. J Cell Sci, 121, n. Pt 14, p. 2360-2371, Jul 2008.

SONAL; SIDHAYE, J.; PHATAK, M.; BANERJEE, S. et al. Myosin Vb mediated plasma membrane homeostasis regulates peridermal cell size and maintains tissue homeostasis in the zebrafish epidermis. PLoS Genet, 10, n. 9, p. e1004614, Sep 2014.

STRICKER, J.; BECKHAM, Y.; DAVIDSON, M. W.; GARDEL, M. L. Myosin II-mediated focal adhesion maturation is tension insensitive. PLoS One, 8, n. 7, p. e70652, 2013.

STROM, M.; HUME, A. N.; TARAFDER, A. K.; BARKAGIANNI, E. et al. A family of Rab27-binding proteins. Melanophilin links Rab27a and myosin Va function in melanosome transport. J Biol Chem, 277, n. 28, p. 25423-25430, Jul 2002.

SUN, Z.; GUO, S. S.; FÄSSLER, R. Integrin-mediated mechanotransduction. J Cell Biol, 215, n. 4, p. 445456, Nov 2016.

TAUHATA, S. B.; DOS SANTOS, D. V.; TAYLOR, E. W.; MOOSEKER, M. S. et al. High affinity binding of brain myosin-Va to F-actin induced by calcium in the presence of ATP. J Biol Chem, 276, n. 43, p. 3981239818, Oct 2001.

TRYBUS, K. M. Myosin V from head to tail. Cell Mol Life Sci, 65, n. 9, p. 1378-1389, May 2008. 
TSAKRAKLIDES, V.; KROGH, K.; WANG, L.; BIZARIO, J. C. et al. Subcellular localization of GFP-myosin-V in live mouse melanocytes. J Cell Sci, 112 ( Pt 17), p. 2853-2865, Sep 1999.

VICENTE-MANZANARES, M.; CHOI, C. K.; HORWITZ, A. R. Integrins in cell migration--the actin connection. J Cell Sci, 122, n. Pt 2, p. 199-206, Jan 2009.

VOLKMANN, N.; LIU, H.; HAZELWOOD, L.; KREMENTSOVA, E. B. et al. The structural basis of myosin V processive movement as revealed by electron cryomicroscopy. Mol Cell, 19, n. 5, p. 595-605, Sep 2005.

WADA, F.; NAKATA, A.; TATSU, Y.; OOASHI, N. et al. Myosin Va and Endoplasmic Reticulum Calcium Channel Complex Regulates Membrane Export during Axon Guidance. Cell Rep, 15, n. 6, p. 1329-1344, 052016.

WANG, Y.; WANG, Z. Regulation of EGF-induced phospholipase C-gamma1 translocation and activation by its SH2 and PH domains. Traffic, 4, n. 9, p. 618-630, Sep 2003.

WANG, Z.; HUMPHREY, C.; FRILOT, N.; WANG, G. et al. Dynamin2- and endothelial nitric oxide synthase-regulated invasion of bladder epithelial cells by uropathogenic Escherichia coli. J Cell Biol, 192, n. 1, p. 101-110, Jan 2011.

WOOLNER, S.; BEMENT, W. M. Unconventional myosins acting unconventionally. Trends Cell Biol, 19, n. 6, p. 245-252, Jun 2009.

WU, X.; BOWERS, B.; RAO, K.; WEI, Q. et al. Visualization of melanosome dynamics within wild-type and dilute melanocytes suggests a paradigm for myosin $V$ function In vivo. J Cell Biol, 143, n. 7, p. 18991918, Dec 1998.

WU, X.; BOWERS, B.; WEI, Q.; KOCHER, B. et al. Myosin V associates with melanosomes in mouse melanocytes: evidence that myosin V is an organelle motor. J Cell Sci, 110 ( Pt 7), p. 847-859, Apr 1997.

WU, X.; WANG, F.; RAO, K.; SELLERS, J. R. et al. Rab27a is an essential component of melanosome receptor for myosin Va. Mol Biol Cell, 13, n. 5, p. 1735-1749, May 2002.

WU, X. S.; TSAN, G. L.; HAMMER, J. A. Melanophilin and myosin Va track the microtubule plus end on EB1. J Cell Biol, 171, n. 2, p. 201-207, Oct 2005.

XU, Y. J.; TAPPIA, P. S.; GOYAL, R. K.; DHALLA, N. S. Mechanisms of the lysophosphatidic acid-induced increase in $[\mathrm{Ca}(2+)](i)$ in skeletal muscle cells. J Cell Mol Med, 12, n. 3, p. 942-954, Jun 2008.

YAMASHIRO, S.; WATANABE, N. A new link between the retrograde actin flow and focal adhesions. J Biochem, 156, n. 5, p. 239-248, Nov 2014. 
YAO, L. L.; CAO, Q. J.; ZHANG, H. M.; ZHANG, J. et al. Melanophilin Stimulates Myosin-5a Motor Function by Allosterically Inhibiting the Interaction between the Head and Tail of Myosin-5a. Sci Rep, 5, p. 10874, Jun 2015.

YILDIZ, A.; FORKEY, J. N.; MCKINNEY, S. A.; HA, T. et al. Myosin V walks hand-over-hand: single fluorophore imaging with 1.5-nm localization. Science, 300, n. 5628, p. 2061-2065, Jun 2003.

YOSHIZAKI, T.; IMAMURA, T.; BABENDURE, J. L.; LU, J. C. et al. Myosin 5a is an insulin-stimulated Akt2 (protein kinase Bbeta) substrate modulating GLUT4 vesicle translocation. Mol Cell Biol, 27, n. 14, p. 5172-5183, Jul 2007.

ZHANG, W.; THOMPSON, B. J.; HIETAKANGAS, V.; COHEN, S. M. MAPK/ERK signaling regulates insulin sensitivity to control glucose metabolism in Drosophila. PLoS Genet, 7, n. 12, p. e1002429, Dec 2011.

ZHAO, J.; GUAN, J. L. Signal transduction by focal adhesion kinase in cancer. Cancer Metastasis Rev, 28, n. 1-2, p. 35-49, Jun 2009. 